\title{
Deprem Bölgesinde Bulunan Mevcut Bir Tank Yapısının Geoteknik Değerlendirmesi
}

\author{
E. Ece ESELLER-BAYAT ${ }^{1}$ \\ Onur DENIZ ${ }^{2}$
}

\section{ÖZ}

Bu çalışma TBDY 2018, uluslararası standartları ve literatürdeki çalışmaları esas alarak deprem bölgesinde bulunan mevcut bir tank yapısının deprem yükleri altında geoteknik değerlendirmesini sunmaktadır. Sahada sıvılaşma potansiyeli bulunması ve kayma mukavemeti düşük 35 m'den kalın kil tabakalarının mevcut olması sebebiyle zaman tanım alanında doğrusal olmayan boşluk suyu basıncı modelleri kullanılarak ve kullanılmadan sahaya özel zemin davranış analizleri ayrı ayrı gerçekleştirilmiştir. Zemin yumuşaması ve sıvılaşmasının doğal bir izolatör gibi davranarak yüzey ivmelerini ciddi oranda sönümlediği gözlemlenmiş, ancak serbest sahada yüksek mertebelerde yanal yer değiştirmelere (2.0-2.3 $\mathrm{m})$ ve düşey oturmalara $(58-128 \mathrm{~cm})$ sebebiyet verdiği tahmin edilmiştir. Tank yapisı temelinde oluşacak farklı oturmanın yaklaşık en fazla $70-80 \mathrm{~cm}$, en düşük ise $5-10 \mathrm{~cm}$ mertebelerinde olduğu tahmin edilmekte ve boru bağlantılarında bu yer değiştirme farkının göz önünde bulundurulması önerilmektedir. Üst yapıdan gelecek olan atalet (ilave deprem) yükleri altında tank yapısı tabanında ve geogritli dolgu altında taşıma gücü ve tabanda kayma kontrolleri yapılmış ve güvenli bulunmuştur.

Anahtar Kelimeler: Sismik analiz, tank yapıları, sıvılaşma, TBDY 2018, sahaya özel yer tepki analizleri.

\section{ABSTRACT \\ Geotechnical Evaluation of an Existing Tank Structure Located in a Seismic Zone}

This study presents the geotechnical evaluation of an existing tank structure under earthquake loads, based on TBDY 2018, international standards, and the published models in the literature. Due to the presence of liquefaction potential and clay layers thicker than $35 \mathrm{~m}$ with low shear strength in the field, non-linear site-specific analyses were performed

\footnotetext{
Not: Bu yazı

- Yayın Kurulu’na 21 Ekim 2020 günü ulaşmıştır. 11 Mayıs 2021 günü yayımlanmak üzere kabul edilmiştir.

- 31 Temmuz 2022 gününe kadar tartışmaya açıktır.

- https://doi.org/10.18400/tekderg.813808
}

1 İstanbul Teknik Üniversitesi, İnşaat Mühendisliği Bölümü, İstanbul - ebayat@itu.edu.tr https://orcid.org/0000-0002-5774-4911

2 İstanbul Teknik Üniversitesi, İnşaat Mühendisliği Bölümü, İstanbul - denizonu@itu.edu.tr https://orcid.org/0000-0003-3540-0584 
in the time domain with and without pore pressure models. Soil softening and liquefaction act as a natural isolator, damping surface accelerations significantly, but they have caused high lateral displacements $(2.0-2.3 \mathrm{~m})$ and vertical settlements $(58-128 \mathrm{~cm})$ in the free field. It is estimated that the differential settlement at the tank structure is approximately $70-80$ $\mathrm{cm}$ at the maximum and $5-10 \mathrm{~cm}$ at the lowest that is needed to be considered in pipe connections with the tank at the site. Under the additional earthquake loads from the superstructure, the bearing capacity and sliding control on the bottom of the tank structure and under the fill reinforced with geogrid were found to be safe.

Keywords: Seismic analysis, tank structures, liquefaction, site-specific ground response analysis, TBDY (Turkish Earthquake Resistant Building Design Regulations) 2018.

\section{GİRIŞ}

Deprem bölgelerinde bulunan, endüstriyel yapılar olarak sınıflandırılan tank yapılarının sismik tasarımı can, mal ve ekonomik kayıplara sebebiyet vermesi açısından büyük önem taşımakta olup kritik yapı tasarımı olarak değerlendirebilir. Bu kritik yapılar için ülkemizde henüz bir depreme dayanıklı tasarım yönetmeliği bulunmamakta ve tank yapılarının tasarımı için uluslararası standartlardan yararlanılmaktadır: API Standardı 650 [1], ASCE 7-10 Bölüm 15 [2], Eurocode 1 Part 4 Silo ve Tanklar [3], NZSEE (New Zealand Society for Earthquake Engineering) Depolama Tanklarının Sismik Tasarımı: 2009 [4]. Amerika Petrol Enstitüsü tarafından önerilen API Standardı 650 "Welded Tanks for Oil Storage" petrol ürünlerini depolayan sıvı depolama tankları için tasarım, imalat, montaj ve test için minimum kriterleri belirlemekte olup sismik tasarıma sadece Ek E'de yer vermektedir ve Amerika'da ve diğer dünya ülkelerinde yaygın olarak kullanılmaktadır. ASCE 7-10 Bölüm 15.7'de bina tipi olmayan yapıların sismik tasarımı bölümü altında betonarme depolama tankların sismik tasarımına ait kriterler verilmiş olup, çelik tankların tasarımı için API650'ye yönlendirmektedir. Türkiye'deki mevcut sıvı depolama çelik tankların tasarımı 2030 yıl öncelerine dayanmakta olup tasarımlarında API 650 baz alınmış olduğu tahmin edilmektedir. Ancak son yıllarda, NZSEE tarafından önerilen depolama tanklarının sismik tasarımı standardı sıvı depolama tanklarının sismik tasarımı için en güncel ve detaylı kriterleri içermektedir. Bu standartların tamamında detaylı kriterler, tankların deprem yüklerinin belirlenmesi ve yapısal stabilite kontrollerinin yapılması üzerine yoğunlaşmaktadır. Zemin kaynaklı oluşacak olan hasar ve kriterler, bina temelleri ve duvar yapıları için çoğu yönetmelikte önerilen kriterlere yönlendirilmektedir. Standartlarda temel tasarım kriterleri ankrajlı ve ankrajlı olmayan temeller için verilmiştir. API-650 Ek B bölümünde tank temeli tasarımı için öneriler verilmekte ve zeminin sıvılaşan zemin veya yumuşak kil olması durumunda özel mühendislik hizmeti alması gerektiği ve temel tasarımının taşıma gücü ve izin verilebilir oturmaları sağlayacak şekilde gerçekleştirilmesi gerektiği belirtilmektedir. NZSEE'ye ait standartta ise temel tasarımı açısından en önemli stabilite kontrolleri oturma, taşıma gücü ve yatayda kayma olarak belirtilmiş, sıvılaşan ve zayıf zeminler için ise gerekli kontrollerin yapılması gerektiği belirtilmiştir.

Tank yapılarının tasarım esasları bina yapılarından farklılık göstermektedir. Tank yapılarının genel itibariyle malzeme taşınmasının kolay ve elverişli olmasından dolayı nehir ve deniz kenarlarında inşası planlanmaktadır. Bu bölgelerde inşa edilen yapıların oturduğu zeminlerin ise büyük ölçüde zemin profili boyunca yumuşak ve/veya gevşek özelliklere 
sahip zeminler olduğu görülmektedir. Geniş çapa ve büyük yüksekliklere sahip tank yapılarının içi doldurulduktan sonra zemine aktarılacak gerilmeler yüksek mertebelere ulaşmaktadır. $\mathrm{Bu}$ da taşıma kapasitesi ve oturma miktarı açısından tank tasarımlarını etkilemektedir. Duncan ve D'Orazio [5] 40 adet tank yapısında yaptıkları incelemelerde uygulamada taşıma kapasitesi açısından iki temel stabilite problemi olduğunu belirtmiştir: genel taşıma gücü (base shear) ve kenar taşıma gücü (edge shear) problemi. D'Orazio ve Duncan [6] oturmalar açısından tank yapılarını incelediklerinde ise tank tabanlarının oturdukça çok çeşitli distorsiyonlara maruz kaldığını belirlemişlerdir. Bazı durumlarda maksimum oturma tank merkezi altında gerçekleşirken bazı durumlarda ise tank merkezi ile tank kenarı arasında kalan bölgede oluştuğu gözlemlenmiştir. Depolama tankları esnek yapı olarak kabul edilmekte ve diğer mühendislik yapılarına göre daha büyük oturmalara müsaade etmektedir [6-7]. Literatürde tank tabanı ve tank duvarı arasında $60 \mathrm{~cm}$ ye ulaşan farklı oturmaya sahip hasarsız çalışmaya devam eden vakalar bulunmaktadır. Düzceer [8] beş adet yüzer tavanlı çelik akaryakıt depolama tankında yaptı̆ğ incelemeler sonucunda geniş çapa sahip tank temellerinde oluşmuş $40.8 \mathrm{~cm}$ 'lik oturmanın üst yapıda herhangi bir fonksiyon kaybına sebep olmadığını belirtmiştir. Tank yapılarının oturma miktarları konusunda genel kabul görmüs limitler bulunmamaktadır. Yine de izin verilebilir oturma miktarları sınırsız değildir. Tank yapısında meydana gelecek oturmaların oluşturacağı olası etkiler, tankın genel oturması, tank çapı boyunca oluşacak farklı oturma kaynaklı iç boru bağlantılarını zorlayıcı etkiler, tank çevresi boyunca oluşacak farklı oturma kaynaklı üst yapıyı zorlayıcı ve yüzer tavan sistemine sahip tanklarda bu sistemin çalışmasını engelleyici etkiler ve tank ve çevresi arasında oluşacak farklı oturma kaynaklı dış boru bağlantılarında meydana gelecek etkiler olarak sıralanabilir [9-10]. İçlerinde büyük hacimlerde çevreye zararlı malzemeler barındıran bu tür tanklarda meydana gelecek hasarlar, ciddi çevresel zararlara, insan hayatı kayıplarına ve büyük mali kayıplara neden olmaktadır. Bu yüzden tank tasarımında üst yapı tasarımı kadar temel zemini davranışı ve temel sistemi tasarımı da büyük önem arz etmektedir.

Mevcut veya yeni inşa edilecek olan tank yapılarının sismik geoteknik değerlendirmesi üzerine burada sunulduğu gibi bütün bir değerlendirmeye hem ulusal hem de uluslararası literatürde erişilememiştir. Literatürde tank temelleri altında statik oturmalar ve zemin iyileştirme yöntemlerinden bahsedilmiş [5-6-7], deprem bölgelerinde yapılacak olan tanklarla ilgili sıvılaşma kaynaklı oluşan hasarlardan ve dönmelerden bahsedilmiştir. Sento vd. [11] tarafından sunulan çalışmada sıvılaşan zemin üzerindeki bir tank yapısı modellenmiş ve yine nümerik olarak iyileştirilmiş zemin üzerinde tankın performansı irdelenmiştir. Cubrinowski vd. [12] Japonya'da sıkılaştırılmış kum kolonları ile iyileştirilmiş kazıklı bir tank temeli zeminin Kobe Depremi sırasındaki davranışını sayısal olarak irdelemişlerdir.

Tank yapı tasarımlarında takip edilecek bir yönetmelik ülkemizde henüz bulunmamaktadır. $\mathrm{Bu}$ yüzden çalışma kapsamında geoteknik değerlendirmesi yapılan tank için gerekli kontroller 1 Ocak 2019 tarihi itibariyle yürürlüğe giren Türkiye Bina Deprem Yönetmeliği, TBDY-2018 [13], esas alınarak gerçekleştirilmiştir. Bu kapsamda inceleme sahasına ait zemin araştırmaları yapılmış ve arazi zemin modeli oluşturulmuş, mevcut tank temeli sistemi irdelenmiştir. Yapının deprem riskinin yüksek olduğu bir bölgede bulunması sebebiyle tasarım spektrumu belirlenmiş ve temel zeminin deprem etkisi altında sıvılaşma riski değerlendirilmiştir. Sıvılaşma analizleri sonucunda sahaya özel zemin davranış analizleri yapılmış, deprem yükleri altında zeminde oluşacak yer değiştirmeler tahmin 
edilmiş ve tank yapısı temellerinin TBDY 2018'e göre deprem yükleri altında stabilite kontrolleri sağlanmıştır.

\section{ARAZI ZEMIN MODELININ OLUŞTURULMASI}

Geoteknik değerlendirmesi yapılan tank yapısı Marmara denizine $300 \mathrm{~m}$ mesafede bulunmaktadır. Güvenlik sebebiyle kesin konum bilgisi veremediğimiz yapının bulunduğu alan, deprem geçmişi açısından oldukça aktif bir bölgede yer almaktadır (Şekil 1a). İnceleme sahasının yakınında bulunan diri faylar Maden Tetkik ve Arama tarafından oluşturulan diri fay haritası kullanılarak incelenmiştir. İnceleme sahasının yakınında Kuzey Anadolu, Orhangazi ve Yalakdere doğrultu atılımlı fayları ile Yalova normal fayı ve Altınova ters fayının bulunduğu tespit edilmiştir. Belirtilen fay kaynaklarına ait deprem tarihçesine bakıldığında deprem moment büyüklükleri $7.5^{\prime} \mathrm{e}$ varan birçok deprem gerçekleştiği görülmüştür.

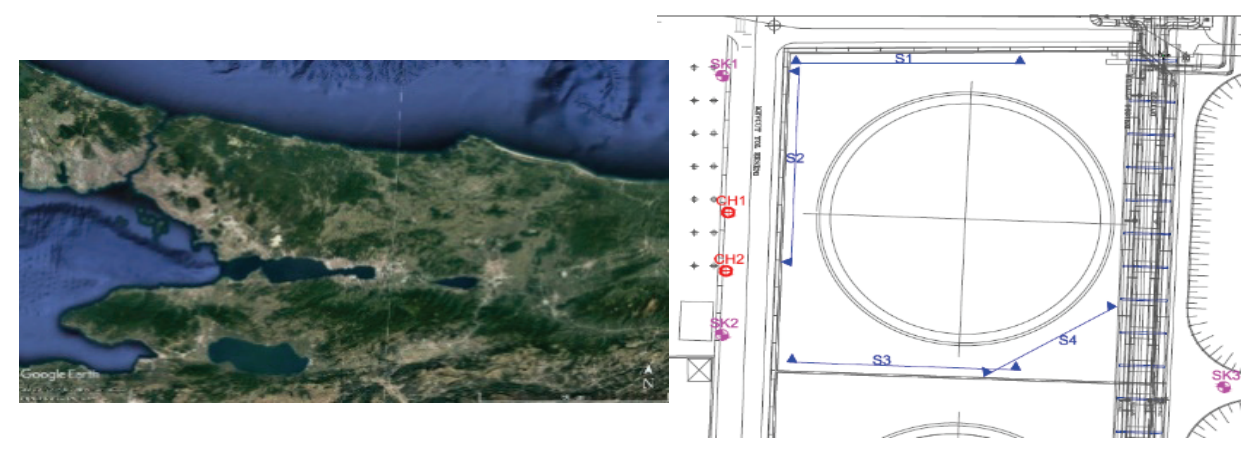

Şekil 1 - (a) Inceleme alanı uydu görüntüsü (Google Earth), (b) Vaziyet planı

\subsection{Zemin Araştırmaları}

İnceleme sahasında tank inşası öncesinde zemin profilini ve zemine ait mühendislik parametrelerini belirlemek amacıyla gerçekleştirilen ilk arazi ve laboratuvar çalışmaları 1997 yılında yapılmıştır. 2017 yılında bölgede planlanan yeni tank inşası, yeni sondaj çalışmalarını gerektirmiş ve inceleme sahasının kuzeyinde 8 adet sondaj gerçekleştirilmiştir. 1 Ocak 2019 yılında yeni deprem yönetmeliğinin faal hale gelmesi inceleme sahasında bulunan mevcut tankların temel sistemlerinin TBDY 2018 esas alınarak uygunluğunu incelemeye sebebiyet vermiştir.

İncelenen tank yapısının oturduğu zemine ait modelin belirlenmesi amacıyla tankın çevresinde her biri $30 \mathrm{~m}$ derinlikte toplam 3 adet sondaj gerçekleştirilmiştir (Şekil 1b). Yapılan sondajlar sırasında her 1.5 m'de bir standart penetrasyon deneyi (SPT) yapılmış ve sondajlarda alınan örselenmiş ve örselenmemiş numuneler üzerinde laboratuvar ortamında doğal birim hacim ağırlık, elek analizi, hidrometre, doğal su muhtevası, kıvam limitleri, konsolidasyon, direkt kesme, serbest basınç ve üç eksenli UU (konsolidasyonsuz-drenajsız) basınç deneyleri gerçekleştirilmiştir. Açılan zemin sondajlarından birinde 6 farklı seviyede presiyometre deneyi yapılmıştır. Ayrıca bölgedeki anakaya derinliğini saptamak ve 
yüzeyden itibaren anakayaya kadar profilde yer alan tabakaların kayma dalgası hızlarını belirlemek amacıyla patlatma metodu kullanılarak 1 adet geniş açılımlı 2 atı̧̧ı 1 2B MASW çalışması gerçekleştirilmiş̧tir. Bunun yanısıra 1 adet karşıt kuyu (cross-hole $\mathrm{CH}$ ) ve 4 adet sismik kırılma-MASW çalışmaları da yapılmıştır (Şekil 1b).

$\mathrm{Bu}$ çalışmada oluşturulan zemin modeline ait profilin ilk 30 metresindeki tabakalar ve mühendislik parametreleri SPT darbe vuruş sayıları $\left(\mathrm{N}_{60}\right)$, presiyometre deney sonuçları ve yukarıda bahsedilen laboratuvar deney sonuçları ortak değerlendirilerek tahmin edilmiş̧ir. Arazi ve laboratuvar deney sonuçlarına göre zemin tabakalarına ait drenajlı ve drenajsız kayma mukavemeti parametreleri ve elastisite modülü değerleri sirasiyla Stroud [14], Baguelin [15], Hatanaka ve Uchida [16], Kulhawy ve Mayne [17] ile Briaud [18] tarafindan önerilen bağıntılar kullanılarak tahmin edilmiş̧ir (Şekil 2). Bölüm 5'de yer alan sahaya özel zemin davranış analizlerinde kullanılmak üzere oluşturulan zemin modelinde ise profilin ilk 30 metreden sonraki bölümü 2B MASW çalışması ile tamamlanmıştır. Oluşturulan zemin modeline ait profilde $0.0-3.5 \mathrm{~m}$ arasında dolgu tabakası, $3.5-7.0 \mathrm{~m}$ arasında silt içerikli düşük plastisiteli çok yumuşak kil tabakası, 7.0-11.5 m arasında çakıl içerikli killi orta sıkı kum tabakası, 11.5-20.0 m arasında silt içerikli kum arabantlı yumuşak kil tabakası ve 20.0$30.0 \mathrm{~m}$ arasında silt içerikli kum arabantlı orta katı-katı kil tabakası olarak tahmin edilmiştir. Yapılan 2B MASW çalışması ile yüzeyden itibaren 150 metre derinlik için kayma dalgası hızının derinlikle değişimi profili elde edilmiş ve anakayaya ulaşılamamıştır (Şekil 5). Sahada yapılan 2B MASW ve karşıt kuyu ölçümleri göz önüne alınarak temel seviyesinden itibaren 30 metre derinliğe kadar devam eden zemin profili için ortalama kayma dalgası hızı $\left(\mathrm{V}_{\mathrm{s}}\right)_{30}=109 \mathrm{~m} / \mathrm{s}$ olarak hesaplanmıştır.

\subsection{Yerel Zemin Sinıfı ve Tasarım Spektrumunun Belirlenmesi}

Tank yapılarının tasarımında kullanılacak deprem yer hareketi düzeyinin belirlenmesi için ülkemizde herhangi bir kriter bulunmamaktadır. Genel olarak, kritik yapıların tasarımında sahaya özel sismik tehlike analizleri tasarımda önerilse de uluslararası standartlarda burada bahsedilen tank yapıları için zorunlu kılınmamıştır. Bununla beraber genellikle kritik yapıların tasarımında 2475 yıllık deprem düzeyi (50 yılda bir aşılma olasılığı $2 \%$ olan) kullanılması önerilir. API-650 Bölüm EC.4 'e göre de depremlerin daha sıklıkla gözlemlendiği bölgelerde 475 yıllık depremin (50 yılda bir aşılma olasılı̆̆ $10 \%$ ) minimum şart olarak kullanılacağı belirtilmiştir. Bölgeye ait deprem hareketinin belirlenmesi için tesis yönetimi ve mühendisleri ve üst yapı mühendisliği danışmanlarıyla verilen karara göre DD-2 (475 yıllık: 50 yılda bir aşılma olasıllı̆ı $10 \%$ ) düzeyinde analiz yapılması uygun görülmüştür.

İnceleme sahasina ait harita spektral ivme katsayıları AFAD'a ait https://tdth.afad.gov.tr adresinden herhangi bir deprem yer hareketi düzeyi ve yerel zemin sınıfi esas alınarak kayma dalgası hızı, $\left(\mathrm{V}_{\mathrm{s}}\right)_{30}=760 \mathrm{~m} / \mathrm{s}$ olan mostra için $\% 5$ sönüm oranında kısa periyot harita spektral ivme katsayısı, $\mathrm{S}_{\mathrm{s}}$ ve 1.0 saniye periyot için harita spektral ivme katsayıs1, $\mathrm{S}_{1}$ olarak belirlenebilmektedir. Çalışma kapsamında standart tasarım deprem yer hareketi olarak adlandırılan Deprem Yer Hareketi Düzeyi-2 (DD-2) kullanılarak kısa periyot ve 1.0 saniye periyoduna ait harita spektral ivme katsayıları $\mathrm{S}_{\mathrm{S}}=1.527$ ve $\mathrm{S}_{1}=0.412$ olarak belirlenmiştir. $\mathrm{Bu}$ çalışmada temel taban kotundan itibaren $\left(N_{60}\right)_{30}=3$ ve $\left(\mathrm{V}_{\mathrm{s}}\right)_{30}=109 \mathrm{~m} / \mathrm{s}$ olarak belirlenmiştir. $\mathrm{Bu}$ sonuçlar inceleme sahasının yerel zemin sınıfının $\mathrm{ZE}$ olduğunu 
göstermiştir. Yerel zemin etki katsayıları, TBDY 2018 bölüm 2.3.3'de yer alan Tablo 2.1 ve Tablo 2.2 yardımıyla yerel zemin sınıfı ile $S_{S}$ ve $S_{1}$ değerlerine bağlı olarak $F_{S}=0.800$ ve $\mathrm{F}_{1}=2.376$ olarak tespit edilmiş ve kısa periyot tasarım spektral ivme katsayısı, $\mathrm{S}_{\mathrm{DS}}=\mathrm{S}_{\mathrm{s}} \mathrm{F}_{\mathrm{s}}=1.222$, 1.0 saniye periyodu tasarım spektral ivme katsayıs1, $\mathrm{S}_{\mathrm{D} 1}=\mathrm{S}_{1} \mathrm{~F}_{1}=0.979$ olarak hesaplanmıştır. $S_{D S}$ ve $S_{D 1}$ değerleri kullanılarak köşe periyotları $T_{A}=0.160$ ve $\mathrm{T}_{\mathrm{B}}=0.801$ ve yatay elastik tasarım spektral ivme değerleri hesaplanmış ve bu şekilde yatay elastik tasarım ivme spektrumu elde edilmiştir. Yönetmeliğe uygun olarak sabit yerdeğiştirme bölgesine geçiş periyodu $T_{L}=6$ saniye alınmıştır.

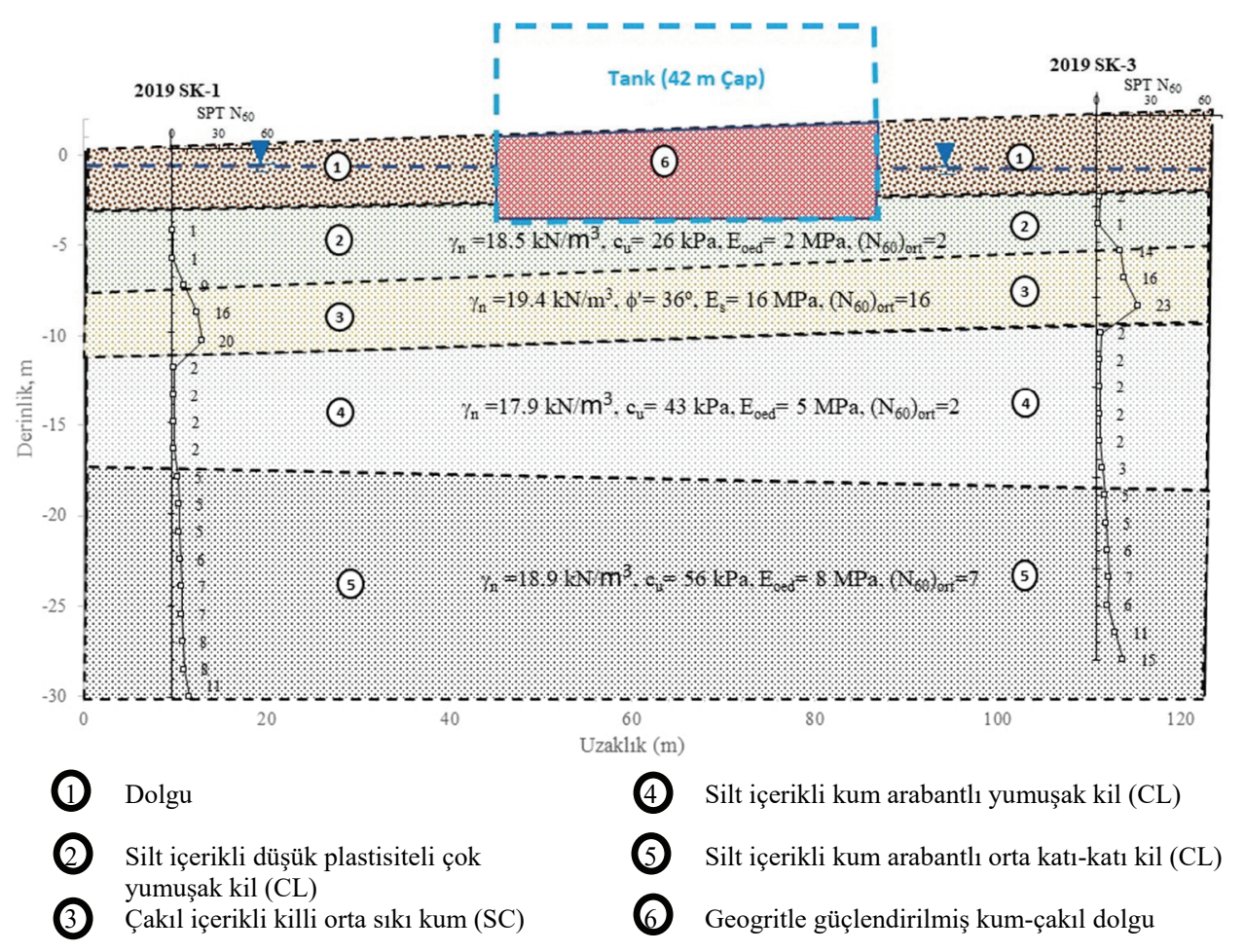

Şekil 2 - Inceleme sahasina ait zemin profili

\section{MEVCUT TANK YAPISI VE TEMEL SISTEMI}

Yüzer çatı tipine sahip inceleme tankı $41.7 \mathrm{~m}$ çapında ve $12 \mathrm{~m}$ yüksekliğinde olup 16000 $\mathrm{m}^{3}$ lük iç hacime sahiptir. İmalat sırasında hazırlanan raporda belirtildiği üzere tankın temel inşası için zemin yüzeyinden itibaren $4.0 \mathrm{~m}$ zemin kazısı yapılmıştır. Zemin kazı kotundan itibaren elenmiş, yıkanmış, granülometrisi ayarlanmış kum-çakıl dolgu malzemesi ile 50 cm'lik tabakalar halinde doldurulmuş ve 25 tonluk vibrasyonlu silindir ile sıkıştırılmıştır. Her sıkıştırma işleminden sonra bir sonraki kum-çakıl kontrollü dolgusu yapılmadan, zemin yüzeyine geogrit malzeme serilerek güçlendirme gerçekleştirilmiştir. 7. geogrit tabakasının üzerine tekrar kum-çakıl dolgusu yapılarak tankın tabanı bu tabaka üzerine oturtulmuştur. Kum-çakıl dolgu malzemesi ve 7 tabaka geogritle güçlendirilmiş zemin üzerine tank taban 
dolgusunu çevreleyen betonarme çevre duvarı inşa edilmiştir. Tank taşıyıcı çevre duvarı temeli $60 \mathrm{~cm}$ kalınlığa ve $290 \mathrm{~cm}$ taban genişliğine sahip olup toplamda $310 \mathrm{~cm}$ yüksekliğindedir. Çevre duvarın ön kısmı da ayrı bir dolgu malzemesi ile doldurulmuş ve aynı silindirle sıkıştırılmıştır. Tank çeperinin alt kısmına $30 \mathrm{~cm}$ x $80 \mathrm{~cm}$ 'lik betonarme iç ring kirişi inşa edilmiştir. Tankın sızdırmazlığını sağlamak amacıyla çevre duvarı üst kotundan itibaren tankın oturacağı çember içi $10 \mathrm{~cm}$ kalınlığında mastik asfalt ile kaplanmış ve tankın doğrudan dolgu malzemesi ile temas etmesi önlenmişsir. Tankın ortasında olan boşaltma nozulu için iç ring kirişinden ortaya doğru asfalt üzerinde $\% 5^{\prime}$ lik bir eğim verilmiş olup kum çakıl dolgu içinde $1.20 \mathrm{~m} \mathrm{x} 0.80 \mathrm{~m}$ ölçülerinde bir tünel yapılmıştır. İç ring kiriş üzerinden çevre duvar üst kotuna doğru yapılan asfalt kaplama \%1 eğim ile teşkil edilmiştir (Şekil 3).

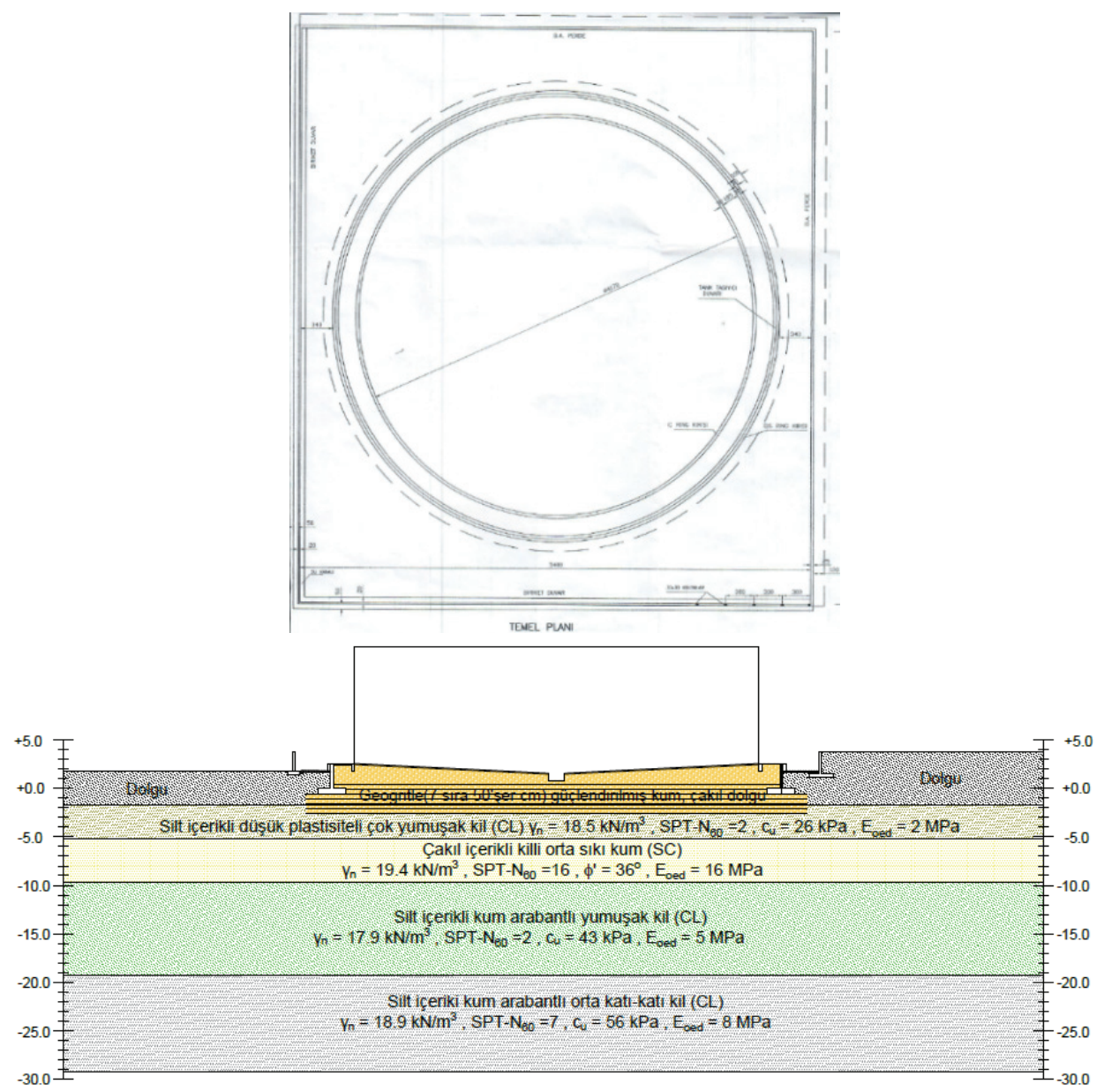

Şekil 3 - Tank temeli idealize zemin kesiti 


\section{DEPREM ETKİSI ALTINDA ZEMIN SIVILAŞMASI VE YUMUŞAMASI RISKININ DEĞERLENDİRILMESI}

Yönetmelikte Kısım 16.6'da hangi durumlarda sıvılaşma potansiyelinin araştırılacağı ifade edilmektedir. Buna göre, Deprem Tasarım Sınıfı DTS=1, DTS=1a, DTS=2 ve DTS=2a olan binalar için yerel zemin sınıfının ZD, ZE veya ZF olması halinde, sürekli bir tabaka veya kalın mercekler halinde bulunup Kısım 16.6.6'da tanımlanan durumlar dışında kalan kumlu zeminlerde sıvılaşma potansiyelinin bulunup bulunmadığının belirlenmesi zorunlu tutulmuştur. Bölüm 2.2'de temel taban seviyesinden itibaren ilk $30 \mathrm{~m}$ ortalama kayma dalgası hızına göre belirlenmiş olan zemin sınıfı ZE için elde edilen tasarım spektrumu kullanılarak TBDY EK 16.B'de bahsedilen yöntemle sıvılaşma analizi gerçekleştirilmiştir. Sıvılaşmaya karşı güvenlik koşulu zeminin sıvılaşma direncinin zeminde deprem hareketi sebebiyle oluşan ortalama tekrarlı kayma gerilmesine oranının en az 1.10 olması koşulu olarak ifade edilmiştir. Sıvılaşma direncinin, $\tau_{R}$, hesaplanması için moment büyüklüğü $\mathrm{M}_{\mathrm{w}}=7.5$ olan depreme karşılık gelen çevrimsel dayanım oranı, $\mathrm{CRR}_{\mathrm{M} 7.5}$, değerinin belirlenmesi gerekmektedir. Bu değer ise ince dane içeriği göz önüne alınarak yeniden hesaplanmış $\mathrm{N}_{1,60 \mathrm{f}}$ kullanılarak elde edilmektedir. Tasarım depremi moment büyüklüğünün 7.5'tan farklı olması durumunda deprem büyüklüğü düzeltme katsayısı, $\mathrm{C}_{M}$ 'nin kullanılması gerekmektedir. Zemin kayma gerilmesi hesabı için gereken en büyük yer ivmesi değeri ise kısa periyot tasarım spektral ivme katsayısının, $\mathrm{S}_{\mathrm{DS}}, \% 40$ '1 olarak alınacaktır. Ancak tasarım depremi büyüklüğünün nasıl belirleneceği konusunda yönetmelikte herhangi bir bilgi yer almamaktadır. Bu sebeple sıvılaşma analizi için gereken deprem büyüklüğünün tespiti için deterministik bir yaklaşım izlenerek proje sahası için deprem tehlikesine katkısı olan en büyük deprem, Akkar vd. [19] tarafindan hazırlanan TDTH'de (Türkiye Deprem Tehlike Haritaları) dikkate alınan deprem katalogları taranarak belirlenmiştir. Buna göre Marmara Bölgesine ait depremler ve deprem tekerrür modeli incelenerek, $\mathrm{M}_{\mathrm{w}}=7.5$ moment büyüklüğünün sıvılaşma analizlerinde kullanılmasının uygun olduğu sonucuna varılmıştır.

$\mathrm{Bu}$ çalışma kapsamında ele alınan mevcut tank yapısının çevresinde yapılmış olan üç sondaja (SK1, SK2 ve SK3) ait düzeltilmiş ve ince dane oranı etkisine göre hesaplanmış $\mathrm{N}_{1,60 \mathrm{f}}$ değerlerinin ve sıvılaşma analizi sonucunda hesaplanan sıvılaşmaya karşı güvenlik sayılarının zemin profili boyunca değişimleri Şekil 4'de verilmiştir. Kayma gerilmesi oranını ifade eden CRR değeri TBDY 2018'de sunulan ve Youd vd. [20] tarafindan verilen denklem ile hesaplanmıştır. Efektif gerilme düzeltmesini ifade eden $\mathrm{K}_{\sigma}$ ise yönetmelikte bulunmamakla birlikte bu çalışmada hesaplara dahil edilmiştir.

Arazi ve laboratuvar deney verileriyle yapılan analiz sonuçlarına göre özellikle derinlik kotları $-4.0 \mathrm{~m}$ ile $-10.0 \mathrm{~m}$ arası değişen kil ve silt içerikli orta sıkı kum tabakalarında sıvılaşmaya karşı güvenlik sayıları 1.10'un altında elde edilmiştir. Zemin kesiti içerisinde kum tabakası altında devam etmekte olan kalın yumuşak ve orta katı kil tabakalarının bulunduğu arazi ve laboratuvar deneylerine göre (SPT $\mathrm{N}_{60}: 2-8, \mathrm{c}_{\mathrm{u}}<50 \mathrm{kPa}$ ) tahmin edilmiştir. $\mathrm{Bu}$ tür kil tabakalarının dinamik yükler altında yüksek deformasyonlara sebebiyet verme riski bulunmaktadır. Sonuç olarak TBDY 2018 yönergelerine göre zemin sınıfı ZF olarak belirlenmiş olup, deprem etkisi altında sahaya özel zemin davranış analizlerinin doğrusal olmayan (nonlinear) zemin modelleri ile yapılması gerekmektedir. $\mathrm{Bu}$ analizler sonucunda zemin sıvılaşması ve yumuşaması kaynaklı yerdeğiştirmeler belirlenmelidir. 

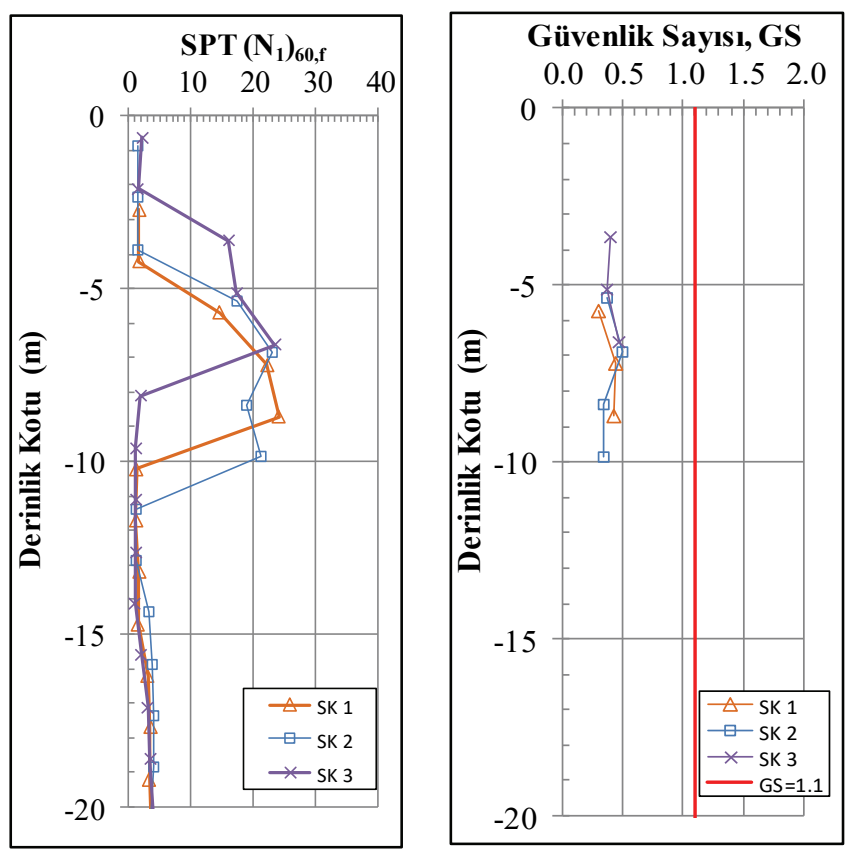

Şekil 4 - SK 1, SK 2 ve SK3 sondajlarına ait (a) SPT-N $N_{1,60 f}$ değerlerinin derinlikle değişimi ve (b) sıvılaşma analizi sonucunda bulunan güvenlik sayısının (GS) derinlikle değişimi

\section{DEPREM ETKISII ALTINDA SAHAYA ÖZEL ZEMIN DAVRANIŞ ANALIZLERİ}

TBDY 2018 ZF yerel zemin sınıfı olarak tanımlanan zeminlerin yüzeyindeki deprem yer hareketini belirlemek üzere sahaya özel zemin davranış analizlerinin yapılmasını zorunlu tutmaktadır. Ayrıca yönetmeliğin kısım 16.5.2.6 maddesinde sıvılaşma potansiyeli olan zeminlerde yapılacak analizlerde zaman tanım alanında doğrusal olmayan analiz yapılması gerektiği açıklanmaktadır. Yine yönetmelikte belirtildiği üzere yap1 çevresinde zemin ortamının yaklaşık olarak yatay tabakalardan oluştuğu durumlarda, sahaya özel zemin davranış analizleri için tek boyutlu yatay tabakalı serbest zemin modelinin kullanılabileceği belirtilmektedir.

İnceleme sahasında serbest zemin modelini oluşturmak, zeminin tabakalaşma durumunu ve zemin modelinde yer alan tabakaların kayma dalgası hızlarını belirlemek ve anakaya derinliğini saptamak amacıyla jeofizik çalışma yapılıış ve yapılan çalışma sonucunda 150 metre derinliğe kadar zemin tabakalarının kayma dalgası hız profili elde edilmiştir (Şekil 5). Bu denli derin tabakalara kadar kayma dalgası hızlarının tahmini için güçlü bir kaynağa ihtiyaç duyulmaktadır (Dikmen vd. [21]). Bu sebeple patlatma yöntemi ile MASW ölçümleri 2 boyutlu olarak gerçekleştirilmiştir. Elde edilen kayma dalgası hız profili sonuçlarına göre anakaya tabakasına ilk 150 metre derinlikte rastlanılmamıştır. Bölge için önceden hazırlanmış jeofizik raporlar incelendiğinde yapılan jeofizik çalışmanın sonucu doğrulanmış ve incelenen raporlarda inceleme sahası bölgesinde anakaya derinliğinin 300 
metre derinlik seviyelerinde olabileceği öngörülmüştür. Ayrıca Şekil 5a'da verilen kayma dalgası derinlik kesiti incelendiğinde kayma dalgası hız dağılımları zeminin yatayda oldukça homojen tabakalaştı̆̆ını göstermektedir. Yönetmelikte belirtildiği üzere sahaya özel zemin davranış analizlerinde kullanılacak serbest zemin modeli oluşturulurken, taban kayasının yapı temelinden itibaren derinliği en büyük yapı genişliğinin üç katından çok daha fazla olması durumunda tabakalı zemin modeli yerel zemin sınıfı ZC veya ZD olan zemin tabakası ile sonlandırılabilecektir. Bu durumda deprem etkisi, taban kayası yerine bu tabakanın üzerinden tanımlanacak ve etkitilmek istenilen deprem kayıtları ZC ya da ZD zemin sınıfına uygun yerel zemin etki katsayıları ile büyütülmüş deprem spektrumlarına uyuşumlu olarak ölçeklendirilmesi gerekecektir. Sahada yapılan sismik kırılma-MASW çalışması çok sığ derinliğe kadar $(12 \mathrm{~m})$ veri sağladığı için etkisi dikkate alınmamıştır. Karşıt kuyu deneyi, 2B MASW verileri ile yakın değerler vermiştir. Sahada yapılan sismik ölçümler göz önüne alınarak temel taban seviyesinden itibaren ilk 30 metre derinliğe kadar devam eden zemin profili için ortalama kayma dalgası hızı $\left(\mathrm{V}_{\mathrm{s}}\right)_{30}=109 \mathrm{~m} / \mathrm{s}$ olarak hesaplanmıştır. Yapılan jeofizik çalışma sonucunda $150 \mathrm{~m}$ derinlikte kayma dalgası hızı $350 \mathrm{~m} / \mathrm{s}$ olarak ölçülmüştür. Yönetmelik Tablo 16.1'de verilen yerel zemin sınıfları için kayma dalgası hız aralığına göre, 150 metre derinlikte ölçülen kayma dalgası hızının $180<$ $350<360 \mathrm{~m} / \mathrm{s}$ aralığında olduğu belirlenmiş ve bu derinlikte ZD zemin sınıfına ait kayma dalgası hızı aralığında kalındığı düşünülerek serbest zemin modeli $150 \mathrm{~m}$ derinlik için DeepSoil v.7 [22] programında oluşturulmuştur. Sondaj çalışmaları sırasında alınan numunelerde yapılan laboratuvar deneyleri, oluşturulan serbest zemin modelinin ilk 30 metresi hakkında bilgi sağlamaktadır. Serbest zemin modelinin 30 metre derinlikten 150 metre derinliğe kadar olan kısmında tabakalaşma belirlenirken sondaj çalışması yapılmamış olmasından dolayı jeofizik çalışma sonucu elde edilen kayma dalgası hız profiline bağlı olarak tabakalaşma modellenmiş ve 30 metredeki orta katı kil tabakasının profil sonuna kadar devam ettiği öngörülerek bu derinlikten itibaren kayma dalgası hızlarına bağlı olarak 6 farklı kil tabakası oluşturulmuştur. $30 \mathrm{~m}$ derinliğinin altında yer alan 6 farklı kil tabakasına ait kayma dalgası hız profili Şekil 5 (b)'de sunulmuştur. Ayrıca, DeepSoil programında zaman tanım alanında yapılacak serbest saha davranış analizlerinde düşük kayma dalgası hızına sahip tabakaların iletebileceği maksimum frekans değerini yüksek tutmak amacıyla ( $f_{\text {maks }}>30 \mathrm{~Hz}$ ) zemin modeli 102 alt tabakaya ayrılmıştır.

Doğrusal olmayan analizler için genelleştirilmiş kuadratik/hiperbolik model $(\mathrm{GQ} / \mathrm{H})$ ve Kondner ve Zelasko tarafından oluşturulan ve Matasovic tarafından modifiye edilen hiperbolik modeller (MKZ) kullanılmıştır. GQ/H modelinde kullanılan zeminin, ilk $30 \mathrm{~m}$ için kayma mukavemeti $\tau_{\max }$ parametreleri, yapılan laboratuvar deneyleri ve arazi deneyi sonuçları ile korelasyonlar kullanılarak belirlenmiştir. $30 \mathrm{~m}$ derinlikte bulunan kil tabakasından itibaren daha derindeki tabakaların zemin mukavemeti değerleri ise Skempton'ın [23] normal konsolide killer için plastisite indisine bağlı olarak verdiği korelasyon $\quad\left(\mathrm{c}_{\mathrm{u}} / \sigma_{\mathrm{v}}{ }^{\prime}=0.11+0.0037 \mathrm{I}_{\mathrm{p}}\right) \quad$ kullanılarak $\mathrm{I}_{\mathrm{p}}=20 \% \quad$ kabulüyle $\quad\left(\mathrm{c}_{\mathrm{u}} / \sigma_{\mathrm{v}}{ }^{\prime}=0.18\right)$ belirlenmiştir (Şekil 5b). Maksimum kayma modülü, kayma dalgası hızı kullanılarak elastik bağıntı ile elde edilmiştir $\left(\mathrm{G}_{\text {maks }}=\rho \mathrm{V}_{\mathrm{s}}{ }^{2}\right)$. Darendeli [24] tarafından önerilen kayma modülü azalım eğrilerine uygun olacak şekilde 5 adet doğrusal olmayan GQ/H zemin model parametreleri $\left(\theta_{1}, \theta_{2}, \theta_{3}, \theta_{4}\right.$ ve $\left.\theta_{5}\right)$ belirlenmiştir. MKZ modelinde oluşturulan zemin tabakalarına ait model parametreleri de Darendeli tarafından önerilen kayma modülü azalım eğrilerine uygun olacak şekilde belirlenmiştir. Oluşturulan modelde belirli derinliklerdeki kayma modülü azalım eğrileri ve sönüm oranı eğrileri Şekil 6'da verilmiştir. Oluşturulan iki 
model için de tabaka orta noktalarında kullanılan sahaya özel zemin davranış analizleri model parametreleri Çizelge 1'de verilmiştir. Sahada deprem yükleri anında oluşacak olan drenajsız durum kaynaklı kum zeminlerin sıvılaşma ve killi zeminlerin yumuşama potansiyeli bulunması sebebiyle MKZ doğrusal olmayan modelde boşluk suyu basıncı bünye modelleri kullanılmıştır. DeepSoil programında bulunan kum zeminler için DobryMatasovic ve killi zeminler için Matasovic-Vucetic boşluk suyu basıncı modelleri kullanılmıştır. Böylece zemin sıvılaşması ve yumuşamasının yüzeye aktarılacak olan ivmezaman grafiklerine ve ivme tepki spektrumuna etkisi incelenmiştir.

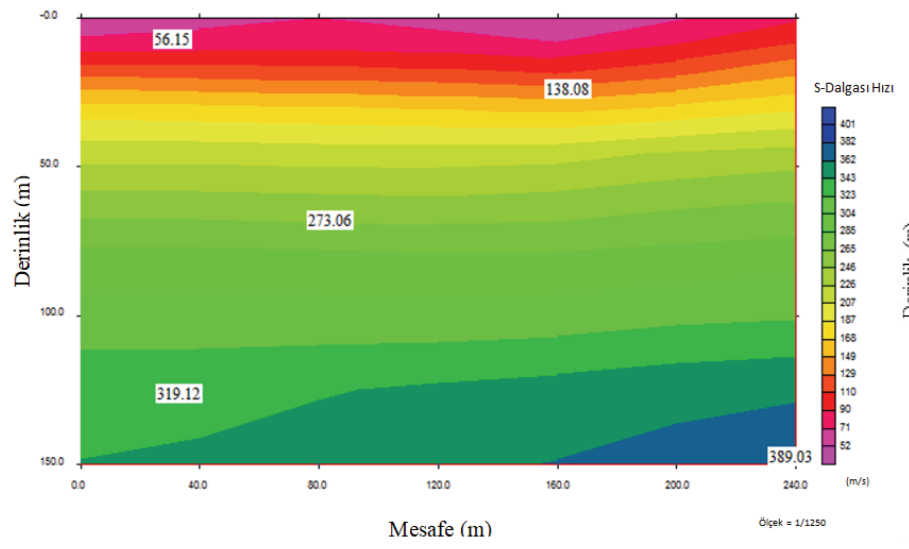

(a)

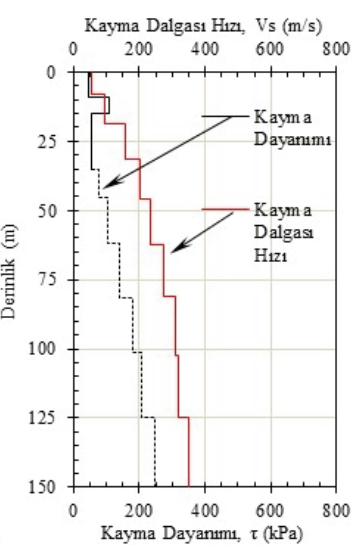

(b)

Şekil 5 - (a) 2B MASW çalışması ile elde edilen kayma (S) dalgası derinlik kesiti (b) Kayma dalgası hızının ve kayma dayanımının derinlikle değişimi

İnceleme sahasında yapılacak sahaya özel zemin davranış analizi için gerekli zemin modeli oluşturulduktan sonra inceleme sahasının sismolojisini yansıtacak deprem kayıtları seçilmiştir. Bu aşamada inceleme sahasının yakınında bulunan diri faylar Maden Tetkik ve Arama tarafından oluşturulan diri fay haritası kullanılarak incelenmiş ve fayların bölgeye uzaklıkları, faylanma mekanizmaları ve ilgili fayda gerçekleşmiş maksimum deprem büyüklüğü belirlenmiştir. Deprem kaydının etkitileceği tabakanın kayma dalgası hızı ve yerel zemin sınıfı yine deprem kayıt seçiminde ki diğer önemli parametrelerdir. Bu çalışma kapsamında Pasifik Deprem Mühendisliği Araştırma Merkezine (PEER) ait https://ngawest2.berkeley.edu sitesi [25] veri tabanı kullanılarak doğrultu atımlı fay (strike slip) üzerinde $\mathrm{R}_{\mathrm{jb}}$ (kuvvetli yer hareketi istasyonunun fay kırığının yüzeydeki projeksiyonuna en yakın mesafesi) türü kaynak mesafesi, $\mathrm{R}_{\mathrm{jb}}<12 \mathrm{~km}$ içerisinde gerçekleşmiş ve $6<\mathrm{M}_{\mathrm{w}}<7.5$ deprem büyüklüğüne sahip, depremin kaydedildiği istasyon zemininin kayma dalgası hızı $200 \mathrm{~m} / \mathrm{s}<\mathrm{V}_{\mathrm{s}}<360 \mathrm{~m} / \mathrm{s}$ değerleri arasında olan iki yanal yönde (doğu-batı ve kuzey-güney) 11'er farklı deprem kaydı seçilmiştir. Seçilen deprem kayıtlarına ait bilgiler Çizelge 2'de sunulmuştur. 


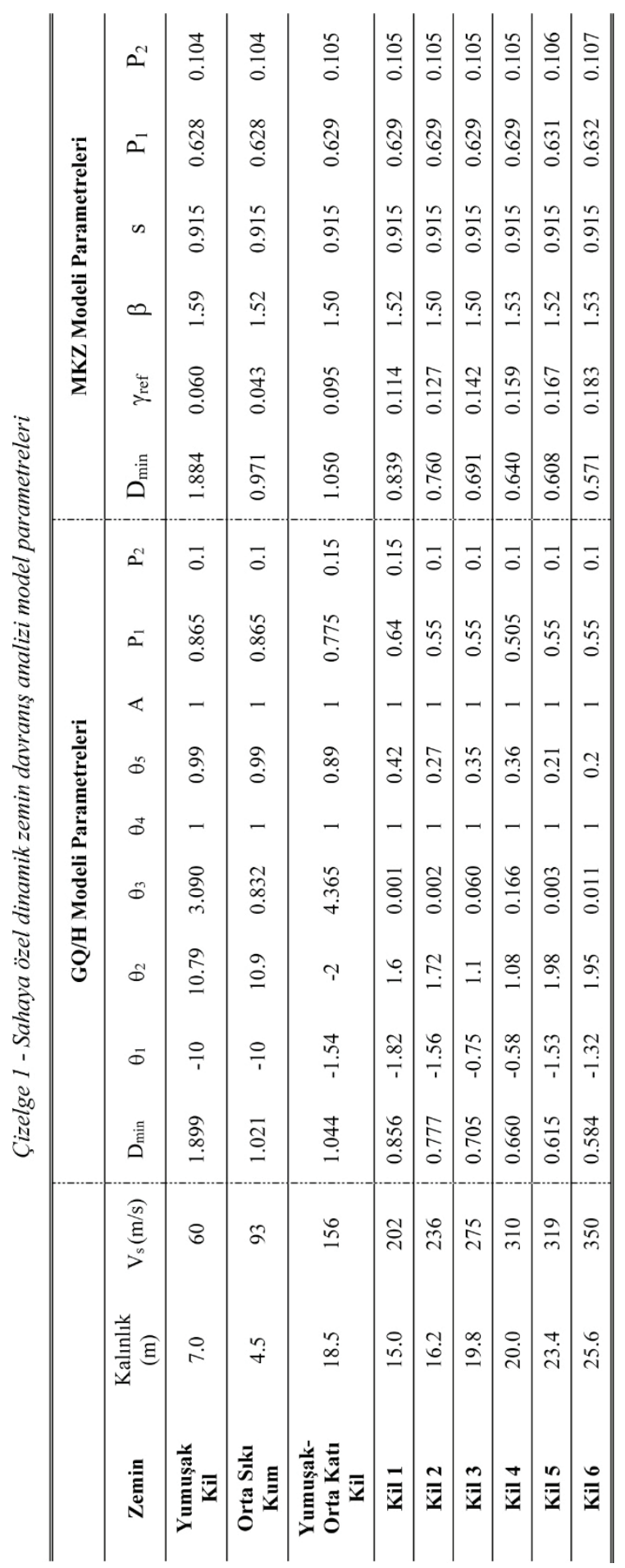




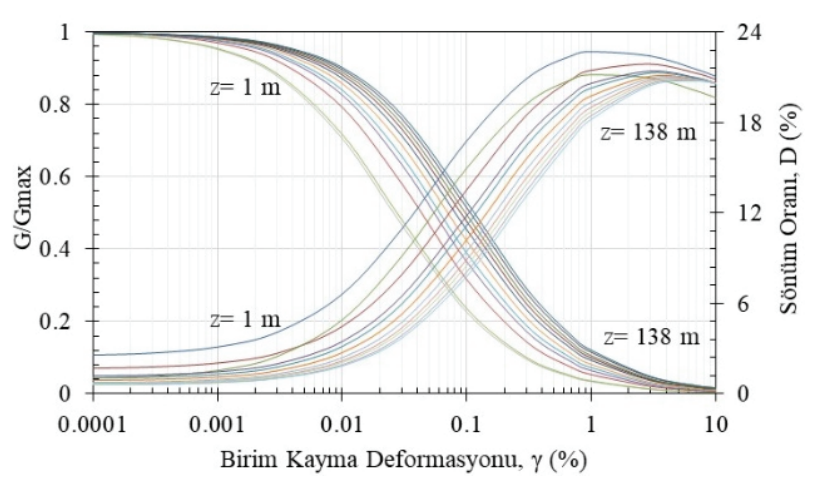

Şekil 6 - MKZ modeli kullanılarak yapılan analizlerde kullanılan normalize kayma modülü ve sönüm oranı ile birim kayma deformasyonu ilişkisi

Çizelge 2 - Analizlerde kullanılan deprem kayıtları ve özellikleri

\begin{tabular}{|c|c|c|c|c|c|c|c|c|c|}
\hline $\begin{array}{l}\text { PEER } \\
\text { Kodu }\end{array}$ & Deprem & Yıl & $\mathbf{M}_{\mathbf{w}}$ & İstasyon & $\begin{array}{c}\text { Fay } \\
\text { Mekanizması }\end{array}$ & $\begin{array}{c}\mathbf{R}_{\mathbf{j b}} \\
(\mathbf{k m})\end{array}$ & $\begin{array}{l}\left(V_{s}\right)_{30} \\
(\mathrm{~m} / \mathrm{s})\end{array}$ & D-B & K-G \\
\hline RSN6 & $\begin{array}{c}\text { Imperial } \\
\text { Valley- } \\
02\end{array}$ & 1940 & 6.95 & El Centro & $\begin{array}{l}\text { Doğrultu } \\
\text { Atımlı Fay }\end{array}$ & 6.09 & 213 & $\begin{array}{c}\text { DEP } \\
1-1\end{array}$ & $\begin{array}{c}\text { DEP } \\
1-2\end{array}$ \\
\hline RSN30 & Parkfield & 1966 & 6.19 & $\begin{array}{c}\text { Cholame } \\
- \\
\text { Shandon }\end{array}$ & $\begin{array}{l}\text { Doğrultu } \\
\text { Atımlı Fay }\end{array}$ & 9.58 & 289 & $\begin{array}{c}\text { DEP } \\
2-1\end{array}$ & $\begin{array}{c}\text { DEP } \\
2-2\end{array}$ \\
\hline RSN95 & $\begin{array}{l}\text { Managua } \\
\text { Nicaragu } \\
\text { a-01 }\end{array}$ & 1972 & 6.24 & $\begin{array}{l}\text { Managua } \\
\text { _ESSO }\end{array}$ & $\begin{array}{l}\text { Doğrultu } \\
\text { Atımlı Fay }\end{array}$ & 3.51 & 288 & $\begin{array}{c}\text { DEP } \\
3-1\end{array}$ & $\begin{array}{c}\text { DEP } \\
3-2\end{array}$ \\
\hline RSN171 & $\begin{array}{c}\text { Imperial } \\
\text { Valley- } \\
06\end{array}$ & 1979 & 6.53 & El Centro & $\begin{array}{l}\text { Doğrultu } \\
\text { Atımlı Fay }\end{array}$ & 0.07 & 264 & $\begin{array}{c}\text { DEP } \\
4-1\end{array}$ & $\begin{array}{c}\text { DEP } \\
4-2\end{array}$ \\
\hline RSN6962 & Darfield & 2010 & 7.00 & ROLC & $\begin{array}{l}\text { Doğrultu } \\
\text { Atımlı Fay }\end{array}$ & 0 & 295 & $\begin{array}{c}\text { DEP } \\
5-1\end{array}$ & $\begin{array}{c}\text { DEP } \\
5-2\end{array}$ \\
\hline RSN723 & $\begin{array}{l}\text { Superstiti } \\
\text { on Hills- } \\
02\end{array}$ & 1987 & 6.54 & $\begin{array}{l}\text { Parachute } \\
\text { Test Site }\end{array}$ & $\begin{array}{l}\text { Doğrultu } \\
\text { Atımlı Fay }\end{array}$ & 0.95 & 348 & $\begin{array}{c}\text { DEP } \\
6-1\end{array}$ & $\begin{array}{c}\text { DEP } \\
6-2\end{array}$ \\
\hline RSN821 & Erzincan & 1992 & 6.69 & Erzincan & $\begin{array}{l}\text { Doğrultu } \\
\text { Atımlı Fay }\end{array}$ & 0 & 352 & $\begin{array}{c}\text { DEP } \\
7-1\end{array}$ & $\begin{array}{c}\text { DEP } \\
7-2\end{array}$ \\
\hline RSN1120 & Kobe & 1995 & 6.90 & Takatori & $\begin{array}{l}\text { Doğrultu } \\
\text { Atımlı Fay }\end{array}$ & 1.46 & 256 & $\begin{array}{c}\text { DEP } \\
8-1 \\
\end{array}$ & $\begin{array}{c}\text { DEP } \\
8-2 \\
\end{array}$ \\
\hline RSN1605 & Düzce & 1999 & 7.14 & Düzce & $\begin{array}{l}\text { Doğrultu } \\
\text { Atımlı Fay }\end{array}$ & 0 & 281 & $\begin{array}{c}\text { DEP } \\
9-1\end{array}$ & $\begin{array}{c}\text { DEP } \\
9-2\end{array}$ \\
\hline RSN1114 & Kobe & 2010 & 6.90 & $\begin{array}{c}\text { Port } \\
\text { Island }\end{array}$ & $\begin{array}{l}\text { Doğrultu } \\
\text { Atımlı Fay }\end{array}$ & 3.31 & 202 & $\begin{array}{l}\text { DEP } \\
10-1 \\
\end{array}$ & $\begin{array}{l}\text { DEP } \\
10-2 \\
\end{array}$ \\
\hline RSN6927 & Darfield & 2010 & 7.00 & LINC & $\begin{array}{c}\text { Doğrultu } \\
\text { Atımlı Fay }\end{array}$ & 5.07 & 263 & $\begin{array}{l}\text { DEP } \\
11-1 \\
\end{array}$ & $\begin{array}{l}\text { DEP } \\
11-2\end{array}$ \\
\hline
\end{tabular}

TBDY 2018 bölüm 2.5.3'de belirtildiği üzere bölüm 16.5.2 kapsamında yapılacak sahaya özel zemin davranış analizlerinde tüm periyotlar için deprem kayıtlarının tasarım spektrumuna uyuşum sağlayacak şekilde ölçeklendirilmesi gerekmektedir. Ölçeklendirilen 
deprem yer hareketlerinin spektrumlarının ordinatlarının ortalamaları, tüm periyotlar için tasarım spektrumu ordinatlarından küçük olmamalıdır. Yönetmelikte belirtilen uyuşumun sağlanması amacıyla PEER veri tabanından elde edilen deprem kayıtlarının doğu-batı ve kuzey-güney yönleri (H1 ve H2) ayrı ayrı ölçeklendirilip, ordinatlarının ortalamalarının tasarım spektrumunun üzerinde kalması sağlanmıştır. Ölçeklendirme işlemi SeismoMatch 2020 [26] programında gerçekleştirilmiştir. Belirlenen periyot aralığında yapılan ölçeklemede minimum periyot $0.05 \mathrm{~s}$, maksimum periyot ise $6 \mathrm{~s}$ olarak seçilmiştir. Elde edilen ölçeklenmiş deprem kayıtlarının tepki spektrumları, ortalama spektrum ve ZD tasarım spektrumu ile birlikte Şekil 7'de gösterilmiştir.

Zaman tanım alanında sahaya özel zemin davranış analizi kapsamında oluşturulan doğrusal olmayan GQ/H modeli boşluk suyu basıncı modelleri kullanılmadan (boşluk suyu basıncı oluşumunu dikkate almadan) ve doğrusal olmayan MKZ modeli boşluk suyu basıncı modelleri kullanılarak (boşluk suyu basıncı oluşumu dikkate alınarak) ölçeklenmiş deprem kayıtları mostra kaydı olarak etkitilmiştir.

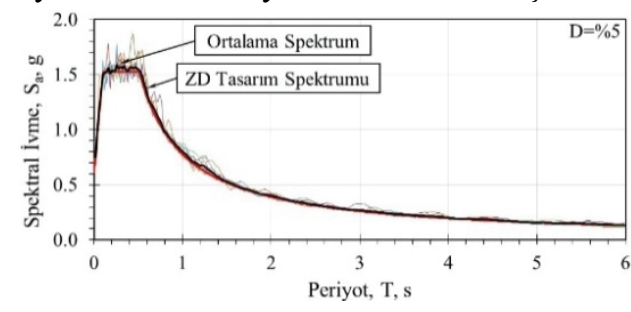

(a)

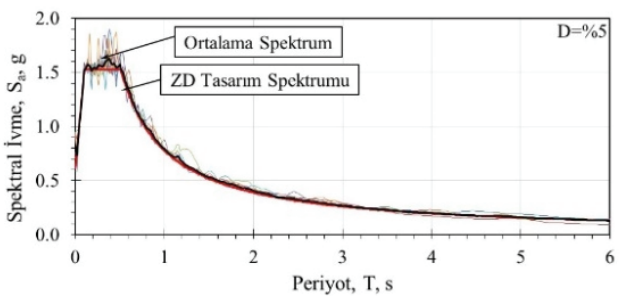

(b)

Şekil 7 - Tasarım spektrumuna ölçeklenmiş 11 adet deprem kaydının tepki spektrumları (a) Doğu-Batı doğrultusu, (b) Kuzey-Güney doğrultusu
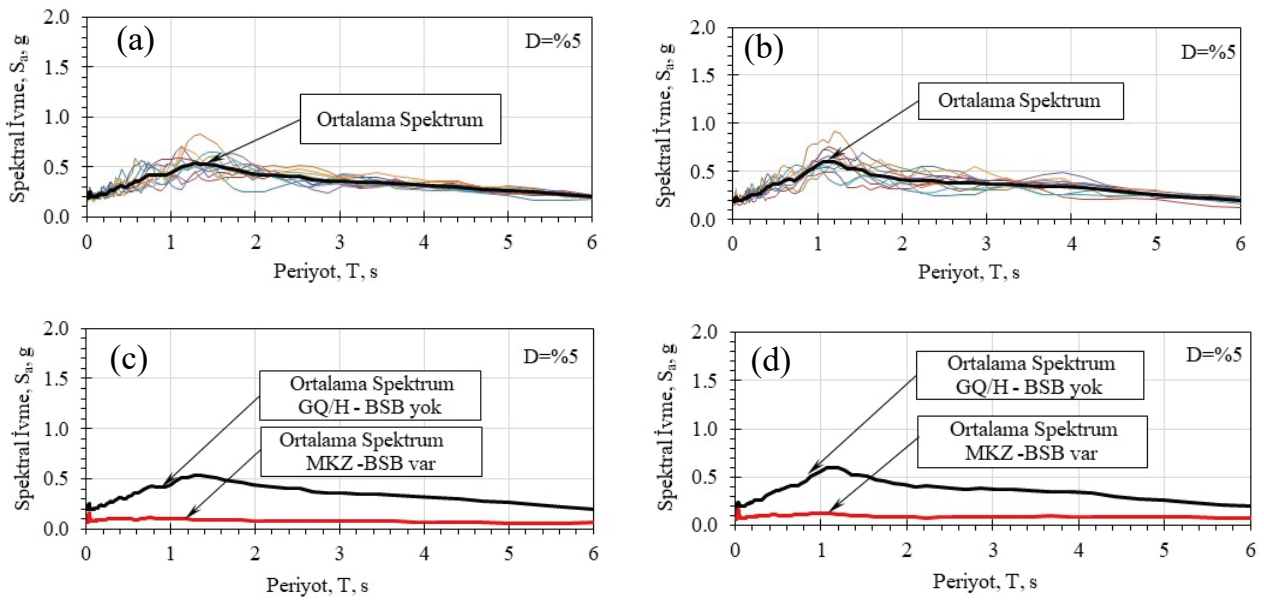

Şekil 8 - Serbest saha analizleri sonucunda yüzeyde elde edilen ivme kayıtlarına ait tepki spektrumları (a) GQ/H Modeli Doğu-Batı (D-B) doğrultusu (b) GQ/H Modeli Kuzey-Güney

$(K-G)$ doğrultusu (c) $G Q / H$ modeli ve $M K Z+B S B$ modeli ortalama spektrumlarl karşılaştırması (D-B) (d) GQ/H modeli ve $M K Z+B S B$ modeli ortalama spektrumları karşılaştırması $(K-G)$ 
Serbest saha analizleri sonucunda yüzeyde elde edilen ivme kayıtlarının tepki spektrumları Şekil 8'de yer almaktadır. Analiz sonuçlarına göre boşluk suyu basıncı modelleriyle gerçekleştirilen doğrusal olmayan analizlerin pik ivmeyi (pga) düşürdüğü ve spektral ivmeleri kayda değer oranda sönümlediği görülmektedir.

\section{ZEMIN SIVILAŞMASI VE ZEMIN YUMUŞAMASI KAYNAKLI ZEMIN YER DEĞISTTIRMELERININ BELIRLENMESI}

Deprem yükleri altında zeminde drenajsı durumun söz konusu olması sebebiyle genellikle kumlu zeminlerin sıvılaşması sırasında oluşan aşırı boşluk suyu basıncının azaltılması için suyun yukarı doğru penetre etmesiyle zeminde düşey deformasyonlar meydana gelir. Ayrıca aşırı boşluk suyunun oluşmass sebebiyle kumlu zeminlerde oluşan mukavemet kaybı sebebiyle yanal yayılmalar da meydana gelir. Aynı şekilde killi zeminlerde drenajsız durumda dinamik etki altında belli miktarda aşırı boşluk suyu basıncı oluştuğu ve yine killerde mukavemet kaybı sebebiyle yanal ve düşey deformasyonların oluştuğu bilinmektedir. Literatürde kum zeminlerde bu deformasyonların belirlenmesi için çeşitli deneysel ve ampirik korelasyonlar geliştirilmiştir (Tokimatsu ve Seed [27-28], Ishihara ve Yoshimine [29], Shamoto vd. [30], Youd vd. [31], Wu vd. [32], Zhang vd. [33], Çetin vd. [34]). Kohezyonlu zeminler için de deprem sonrası oturmalar üzerine literatürde bazı bağıntılar verilmiş ancak bunlar genel olarak boşluk suyu basıncına bağlı olarak geliştirilmiş̧ir ve pratikte uygulaması pek kolay olmamaktadır (Yasuhara vd. [35]). Erken vd. [36] yaptıkları çalışmada killi zeminlerdeki mukavemet ve taşıma gücü kayıplarından bahsetmiş ancak oturmalarla ilgili bir veri veya bağıntı sunmamıştır. Literatürdeki çalışmalar sıvılaşma sonrası oturmalara daha çok yönelirken son yıllardaki çalışmalar hem kohezyonsuz hem de kohezyonlu zeminlerde deprem yüklerinden kaynaklanan deformasyonlarının belirlenmesi gerektiğine dikkat çekmiştir.

TBDY 2018 kısım 16.6.9'a göre sıvılaşma potansiyeli bulunan zemin tabakalarında sıvılaşma riski belirlenirse $(\mathrm{GS}<1.1)$, sıvılaşma kaynaklı yer değiştirmelerin üstyapı-altyapı davranışına etkisi irdelenmelidir. Ancak deprem sırasında yer değiştirmelerin sadece sıvılaşan zeminlerde değil diğer zeminlerde de oluştuğu göz önünde bulundurularak, bu çalışmada hem kum hem de kil zeminlerde yer değiştirmeler hem serbest saha hem de mevcut tank yapısı altında literatürde önerilen yöntem ve bağıntılar kullanılarak tahmin edilmiştir.

\subsection{Serbest Saha Yanal Yer Değiştirmeler}

Tank sahasında deprem yükleri altında serbest saha yanal yer değiştirmeler için sahaya özel analizler ve Çetin vd. [34] ve Unutmaz ve Çetin [37] tarafindan önerilen olasıllksal ve ampirik bağıntılar kullanılmışıtır. Kayma modülü sahaya özel zemin davranışı analizleri sonrasında her tabakada oluşan maksimum yatay şekil değiştirmeye $\left(\gamma_{\max }\right)$ bağlı olarak bulunurken, $v^{\prime}=0.30$ kabul edilmiştir. Doğu-Batı ve Kuzey-Güney yönünde 11 'er deprem kaydı altında yapılan analizler sonucunda elde edilen ortalama maksimum yanal yer değiştirmelerin derinlikle değişimi Şekil 9'da verilmiştir. Ayrıca Çetin vd. [34], Bilge ve Çetin [38] ve Unutmaz ve Çetin [37] tarafından önerilen $\gamma_{\max }$, kumlu zeminler için Denklem 1'de ve killi zeminler için Denklem 2'de verilen olasılıksal bağıntılar kullanılarak SK-1 
verilerine göre tahmin edilmiştir. Bu bağıntılar kullanılarak elde edilen maksimum yanal yer değiştirmeler Şekil 9'da serbest saha analiz sonuçlarıyla karşılaştırılmıştır.

$$
\begin{aligned}
& \gamma_{\text {max }}=\frac{-0.025 \cdot N_{1,60, C S}+\ln \left(C S R_{S S, 20,1-D, 1 a t m}\right)+2.613}{0.004 \cdot N_{1,60, C S}+0.001} \\
& \gamma_{\text {max }}=21.509 \cdot \frac{21.788^{0.092 \cdot\left(\frac{w_{c}}{L L}\right) \cdot \ln \left(\frac{F C}{0.00067}\right)}}{\ln (P I \cdot F C / 61.843)} \cdot\left(1-0.061 \cdot \ln \left(\frac{29.878}{P I \cdot F C}\right)\right) \times \frac{3.473-\sqrt{\left(\frac{\tau_{s t}}{c_{u}}-1.007\right)^{2}+\left(\frac{\tau_{c y c}}{c_{u}}+3.262^{*}\right)^{2}}}{3.473-17.805}
\end{aligned}
$$

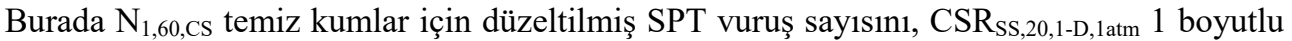
basit kesme deneylerinde 20 . çevrimde $100 \mathrm{kPa}$ düşey efektif gerilme altında çevrimsel gerilme direnci oranını, $\mathrm{w}_{\mathrm{c}}$ su muhtevasını, LL likit limiti, PI, plastisite indisini, FC ince dane oranını, $\tau_{\mathrm{st}}$ statik kayma gerilmesini, $\tau_{\text {cyc }}$ çevrimsel kayma gerilmesini ifade

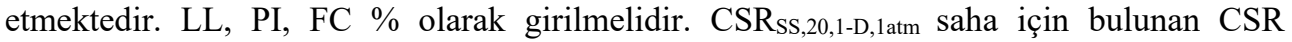
değerine Denklem 3'de belirtilen düzeltmeler yapılarak elde edilmektedir.

$$
C S R_{S S, 20,1-D, 1 a t m}=\frac{C S R_{\text {saha }}}{K_{m d}(z) \cdot K_{M_{w}}(z) \cdot K_{\sigma}(z)}
$$

Burada, $K_{m d}$, çok yönlü deprem hareketi için, $K_{M w}$ deprem büyüklüğü için, $K_{\sigma}$ ise $100 \mathrm{kPa}$ efektif gerilme için düzeltme katsayılarını ifade etmektedir. Bu denklemlerin detayları Çetin vd. [34] tarafından verilmiştir. Her bir zemin tabakası için Denklem 4'de verilen her bir tabakada oluşan birim yer değiştirmelerin tabaka kalınlıkları ile çarpılıp toplanması ile DPI $_{\text {dev }}$ (Deviatoric Displacement Potential Index) değerleri tahmin edilmiştir. $30 \mathrm{~m}$ derinlikten yukarı doğru her derinlik seviyesinde hesaplanan DPI değeri en büyük yanal yer değiştirme $\mathrm{L}_{\max }$ olarak ifade edilmiş ve serbest saha analiz sonuçlarıyla kıyaslanmıştır (Şekil 9).

$$
D P I_{d e v}=\sum_{i=1}^{n} \gamma_{\max , i} \cdot h_{i}+\sum_{j=1}^{k} \gamma_{\max , j} \cdot h_{j}
$$

Yanal yer değiştirme tahminlerine göre, boşluk suyu basıncı kaynaklı yanal yer değiştirmeler yaklaşık $30.0 \mathrm{~m}$ derinlikten yüzeye doğru etkili olmaya başlamıştır. Çetin vd. [34] tarafindan önerilen bağıntılar ile tahmin edilen yanal yer değiştirmeler Kuzey-Güney yönündeki deprem kayıtları ile yapılan boşluk suyu basıncını dikkate alan doğrusal olmayan MKZ modeli sonuçlarıyla yaklaşık olarak yakın tahminler vermiş olup yüzeydeki maksimum yanal yer değiştirmeler Çizelge 3'de verilmiştir.

\footnotetext{
†Makalenin orjinalindeki ifadenin önündeki "-" işareti orjinal makalede şehven yazılmış olup yazar ile iletişime geçilerek bu makalede "+" olarak düzeltilmiştir.
} 

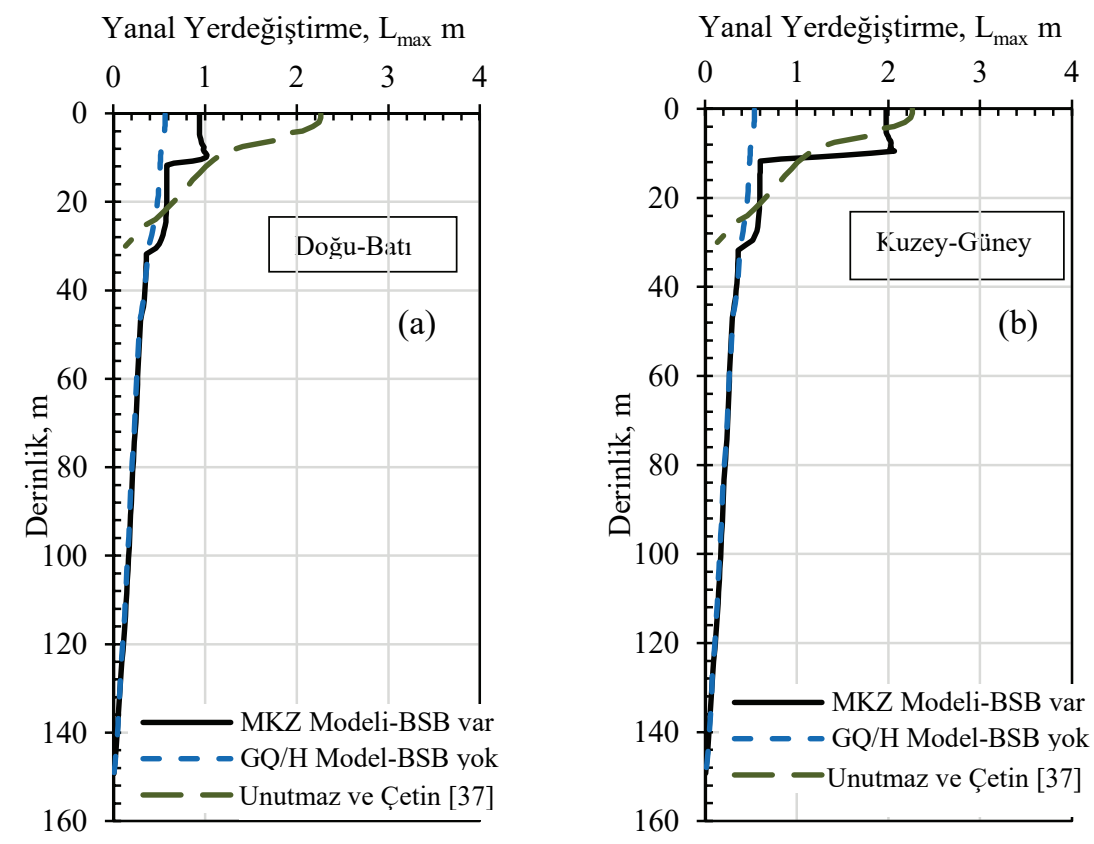

Şekil 9 - Yüzeyde elde edilen yanal yerdeğiş̧tirmeler (a) Doğu-Batı (D-B) doğrultusu (b) Kuzey-Güney $(K-G)$ doğrultusu

\subsection{Serbest Saha Koşullarında Düş̧ey Yer Değiştirmeler}

Bu çalışmada hem kumlu hem killi zeminlerin bulunması sebebiyle düşey yerdeğiştirmeler bu zeminlerde oluşacak olan artık boşluk suyu basıncının sönümlenmesi sonucu oluşacak olan konsolidasyon oturması olarak değerlendirilmiştir. Artık boşluk suyu basıncının sönümlenmesi ile oluşan düşey yerdeğiştirmelerin tahmini için Chiaradonna vd. [39] tarafından önerilen boşluk suyu basıncı bünye modelleriyle yapılan sahaya özel analizlerinin kullanıldığı yaklaşım uygulanmıştır. Buna göre düşey yerdeğiştirme, artık boşluk suyu basıncının sönümlenmesi neticesinde artan düşey efektif gerilmenin $\left(\Delta \mathrm{u}=\Delta \sigma_{z}^{\prime}\right)$, hacimsel sıkışma modülüne $\left(\mathrm{E}_{\text {oed }}\right)$ bölünmesi ile belirlenen düşey şekil değiştirmenin, tabaka kalınlığı $(\Delta z)$ ile çarpılması sonucunda elde edilmektedir (Denklem $5)$.

$S=\sum_{i=1}^{N} \frac{\Delta \sigma_{z, i}}{E_{\text {oed }, i}} \Delta z_{i}$

Yukarıda verilen denklemde bulunan $E_{\text {oed, }}$, kayma modülü $(G)$ ve Poisson oranı $\left(v^{\prime}\right)$ kullanılarak Denklem 6 ile hesaplanmıştır.

$E_{\text {oed }}=\frac{2 G\left(1-v^{\prime}\right)}{\left(1-2 v^{\prime}\right)}$ 
Kayma modülü sahaya özel zemin davranışı analizleri sonrasında her tabakada oluşan maksimum yatay şekil değiştirmeye $\left(\gamma_{\max }\right)$ bağlı olarak azaltılmış sekant modülü olarak bulunurken, $v^{\prime}=0.30$ kabul edilmiştir. Boşluk suyu basıncı modelleriyle gerçekleştirilen doğrusal olmayan serbest saha analizi sonuçlarına göre doğu-batı yönü için ve kuzey-güney yönü için yapılan hesaplar sonucunda ortalama maksimum oturmalar Şekil 10'da sunulmuştur.

Ayrıca, literatürde deprem yükleri altında hem killi hem kumlu zeminlerde düşey yerdeğiştirmeleri tahmin edebilen Çetin vd. [34] ve Bilge ve Çetin [38] tarafından önerilen hacimsel birim sıkışma bağıntıları $\left(\varepsilon_{\mathrm{v}}\right)$ Denklem 7 kum zeminler için, Denklem 8 kil zeminler için kullanılmıştır. İlk 30 m için Denklem 9'da verilen bağıntı kullanılarak her bir tabakada oluşan hacimsel birim sıkışmanın tabaka kalınlıkları ile çarpılıp toplanması ile $\mathrm{DPI}_{\text {vol }}$ (Volumetric Displacement Potential Index) değerleri tahmin edilmiştir. $30 \mathrm{~m}$ derinlikten yukarı doğru her derinlik seviyesinde hesaplanan $\mathrm{DPI}_{\mathrm{vol}}$ değeri en büyük düşey yer değiştirme veya oturma $S_{\max }$ olarak ifade edilmiş ve serbest saha analiz sonuçlarıyla kıyaslanmıştır (Şekil 10), (Çizelge 3).

$$
\begin{aligned}
& \varepsilon_{v}=1.879 \cdot \ln \left[\frac{780.416 \cdot \ln \left(C S R_{S S, 20,1-D, 1 a t m}\right)-N_{1,60, C S}+2442.465}{636.613 \cdot N_{1,60, C S}+306.732}\right]+5.583 \\
& \varepsilon_{v}=\frac{0.4 \cdot \gamma_{\max }^{0.562}}{1.805-0.036 \cdot \ln (P I)-\left(\frac{w_{c}}{L L}\right)} \\
& D P I_{v o l}=\sum_{i=1}^{n} \varepsilon_{v, i} \cdot h_{i}+\sum_{i=1}^{k} \varepsilon_{v, j} \cdot h_{j}
\end{aligned}
$$

Şekil 10'da sunulan karşılaştırmalara göre serbest saha analizi sonucu konsolidasyon oturmalarının, 30 m'den yaklaşık 12 m'ye kadar Unutmaz ve Çetin [37] bağıntıları kullanılarak elde edilen düşey yer değiştirmelere yakın sonuçlar verdiği ancak $12.0 \mathrm{~m}$ derinlikten yüzeye kadar konsolidasyon oturma hesabı ile elde edilen düşey yer değiştirmelerin daha fazla olduğu görülmüştür. $\mathrm{Bu}$ farklılıklar kullanılan modellerin farklılığından ve Unutmaz ve Çetin [37] bağıntılarında deprem bilgisi olarak ortalama pga ve deprem büyüklüğü kullanılırken, serbest saha analizlerinde sahaya özel ivme-zaman kayıtlarının kullanılmasından kaynaklandığı düşünülebilir. Ayrıca serbest saha doğrusal olmayan analizler BSB kaynaklı zemindeki yumuşama ve sönümlemeleri analiz sırasında hesaba kattığı için daha fazla deformasyonlar elde edilmiş olabileceği tahmin edilmektedir. Ayrıca yaklaşık 6-10 m derinlikleri arasında bulunan kumlu zeminlerdeki oturmaların killi zeminlerdeki oturmalardan daha fazla geldiği görülmektedir. Kum zeminlerdeki oturmanın killi zeminlere göre daha fazla gelmesi aşırı boşluk suyu basıncının daha fazla oluşması ve bunun sonucunda oluşan konsolidasyon oturmasının daha fazla olması olarak düşünülebilir. 

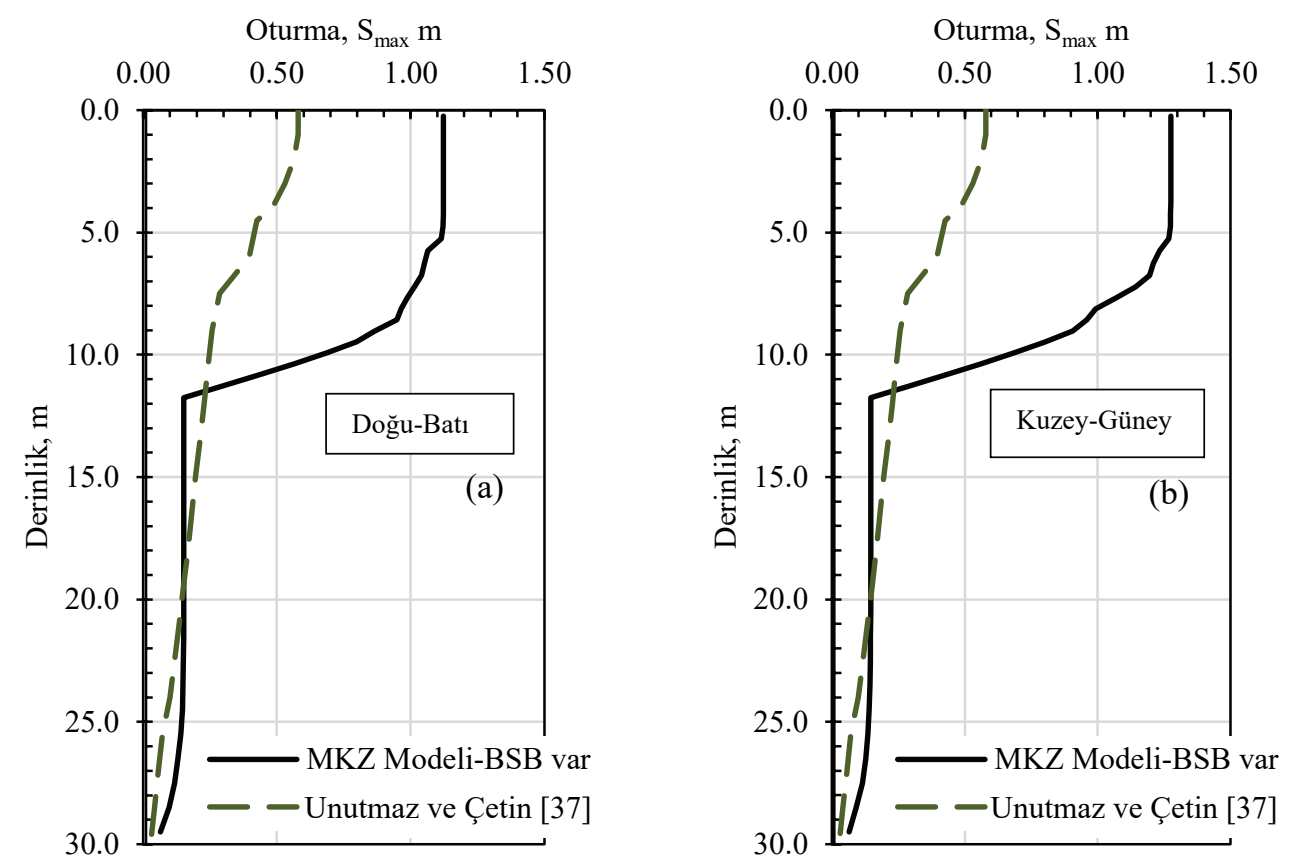

Şekil 10 - Serbest saha analizleri sonucunda ve Unutmaz ve Çetin'e [37] göre yüzeyde elde edilen oturma (a) Doğu-Batı (D-B) doğrultusu (b) Kuzey-Güney (K-G) doğrultusu

Çizelge 3 - Serbest Sahada Dinamik Yükler Altında Tahmin Edilen Yer Değiştirmeler

\begin{tabular}{ccccc}
\hline & \multicolumn{2}{c}{ Doğu-Batı } & \multicolumn{2}{c}{ Kuzey-Güney } \\
\hline Analiz & $\mathbf{L}_{\text {max }}, \mathbf{c m}$ & $\mathbf{S}, \mathbf{c m}$ & $\mathbf{L}_{\text {max }}, \mathbf{c m}$ & $\mathbf{S}, \mathbf{c m}$ \\
\hline GQ/H -BSB yok & 43 & - & 54 & \\
\hline MKZ -BSB var & 94 & 112 & 197 & 128 \\
\hline Unutmaz ve Çetin [28] & 226 & 58 & 226 & 58 \\
\hline \hline
\end{tabular}

\subsection{Tank Yapısı Altında Düşsey Yer Değiştirmeler}

Yapı altında sıvılaşma kaynaklı düşey yer değiştirmeler üzerine son yıllarda güncel çalışmalar yapılmıştır (Dashti vd. [40-41], Wu [42], Bray ve Marcedo [43]). Bu çalışmalarda temel altı zemin sıvılaşması sebebiyle oluşan oturma mekanizmalarının konsolidasyon oturmasının yanı sıra daha çok deprem sırasında temel zemini mukavemet kaybı sonucu oluşan ve temel zeminin dışarı taşınması ve fişkırması sonucu oluşan oturmalardan oluştuğu deneysel olarak gösterilmiş ve olasılıksal bağıntılar sunulmuştur. Ancak bu çalışmalarda sunulan tahmin modelleri sahada sadece sıvılaşan zemin bulunması durumunda ve geniş radye temeller için önerilmiştir. Bu çalışmada sahada hem yumuşama potansiyeli olan killer hem de daha az kalınlıkta sıvılaşan tabaka bulunması sebebiyle, hem 
killerdeki yumuşamayı hem de kumlarda sıvılaşmayı dikkate alan serbest saha ile yapı arasındaki farklı yer değiştirmeler ve dönmeleri tahmin eden Unutmaz ve Çetin [37] tarafından önerilen olasılıksal model bağıntıları kullanılmıştır. Bu model kumlu ve killi zeminlerde yapı altında deprem sonrası oturmaların tahmin edilmesi için geliştirilmiş ve yine Denklem 7 ve Denklem 8 kullanılarak oturmaları tahmin etmektedir. Bu denklemlerde bu sefer yap1 altında oluşan, yapı-zemin etkileşimini de dikkate alan sismik kayma gerilmeleri veya kayma gerilme oranı (CSR $\left.\mathrm{CSEI}_{\mathrm{S}}\right)$ girdi olarak kullanılmaktadır. $\mathrm{CSR}_{\mathrm{SSEI}}$ için Denklem 10'da verilen bağıntı Unutmaz ve Çetin [37] tarafından önerilmiştir:

$$
C S R_{e q, S S E I, \alpha=0, \sigma_{v}^{\prime}=100 k P a}(z)=\theta_{1} \cdot\left(\frac{\theta_{2} \cdot f(\sigma) \cdot f\left(\frac{S_{A}(T)}{P G A}\right) \cdot f\left(\frac{h}{B}\right) \cdot \tau_{b, \text { max }}(z)+\tau_{\text {soil }, \text { max }}(z)}{\sigma_{v, S S I}^{\prime}(z) \cdot K_{\alpha}(z) \cdot K_{\sigma}(z)}\right)^{\theta_{3}}
$$

Bu denklemde $f(\sigma), f\left(\frac{S_{A}(T)}{P G A}\right), f\left(\frac{h}{B}\right)$ yapı-zemin etkileşimi iştirak fonksiyonlarını ifade etmektedir ve $\sigma$ sahaya özel analizler sonucunda azalmış kayma dalgası hızına $\left(\mathrm{V}_{\mathrm{s}, \text { final }}\right)$ ve yapının periyoduna $(\mathrm{T})$ ve boyutlarına (h: yapı yüksekliği, B: temel genişliği) bağlı bir parametreyi $\left(\sigma=\frac{V_{s, \text { final }} \times T}{h_{\text {efektif }}}\right), \mathrm{S}_{\mathrm{A}(\mathrm{T})}$ yapının spektral ivmesini, PGA: pik yer ivmesini, efektif $=2 \mathrm{~h} / 3$ ifade etmektedir. Tank yapısının periyodu $\mathrm{T}=0.3 \mathrm{~s}, \mathrm{~S}_{\mathrm{A}(\mathrm{T}=0.3 \mathrm{~s})}=0.27 \mathrm{~g}$ olarak girilmiştir. $\mathrm{V}_{\text {s,final }}$ değeri $\mathrm{GQ} / \mathrm{H}$ modeli ile yapılan serbest saha analizlerinden her tabaka için elde edilmiş ve Denklem 10'da girdi olarak kullanılmıştır. $\mathrm{Bu}$ denklemin detayları Unutmaz ve Çetin [37] yayınında bulunmaktadır. Bu denklemdeki istatiksel parametreler

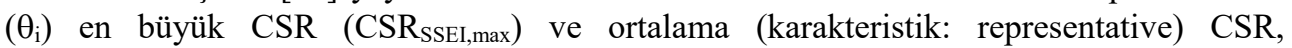
(CSR SSEI,rep$)$ için belirlenmiştir. En büyük değerin yapının köşesinde, temsili değerin ise yapının merkezinde olduğu kabulü yapılmaktadır. Tank yapısı altında $4-4.5 \mathrm{~m}$ mertebelerinde geogritli bir iyileştirilmiş tabaka bulunması sebebiyle oturmalar iyileştirilmiş tabakanın altında hesaplanmıştır. Bu bağıntılara göre yapı altında karakteristik ve maksimum oturma ortalama yaklaşık $50-55 \mathrm{~cm}$ değerleri arasında kaldığı tahmin edilmektedir.

$\mathrm{Bu}$ durumda, iyileştirilmiş tabakanın varlığı ile ortalama oturmalara bakıldığında tank yapısı altında oturmanın serbest sahaya göre daha az olabileceği tahmin edilmektedir. Ancak bu farklı oturmayı tahmin etmek birçok belirsizlik bulundurması sebebiyle oldukça güçtür. Sahaya özel yer tepki analizlerine göre serbest sahada en fazla oturma $128 \mathrm{~cm}$, Unutmaz ve Çetin [37]'e göre $58 \mathrm{~cm}$ olarak bulunmuştur. Bu durumda farklı oturmanın yaklaşık en fazla $70-80 \mathrm{~cm}$, en düşük ise $5-10 \mathrm{~cm}$ mertebelerinde olduğu tahmin edilmektedir. Tank yapısı ile serbest saha arasındaki boru bağlantılarında bu deplasman farkının göz önünde bulundurulması önerilir. 


\section{TANK YAPISI TEMELLERININ TBDY 2018'E GÖRE DEPREM YÜKLERİ ALTINDA STABILITE KONTROLLERI}

Deprem yükleri etkisi altında temel tasarımı için gerçekleştirilmesi gereken stabilite analizleri temel taşıma gücünün aşılmamasının, yapı temelinin yatayda kaymamasının ve zemin yer değiştirmelerinin izin verilebilir sınırlar içerisinde kalmasının kontrolünü gerektirmektedir. Tank yapılarına özel, belirtilen stabilite analizlerinin esas alınacağı bir yönetmeliğimiz bulunmaması sebebiyle, yapıya ait temel sisteminin belirtilen yükleme durumu altında stabilite analizleri TBDY 2018'e göre gerçekleştirilmiştir. Bu çalışmada inceleme tankının temel sistemi bir çok karmaşık geoteknik problemlerin çözümünde kullanılan ve uluslararası standartları ve analitik çözümleri esas alan Fine Yazılımlarından Geo5 [44] analiz programında modellenmiş ve TBDY 2018 standartlarına göre analizleri gerçekleştirilmiştir (Şekil 11).

Stabilite analizlerinde depremli durumda temele etkitilecek düşey yük, eğilme momenti ve taban kesme kuvveti Şekil 8 (a) ve Şekil 8 (b)'de sunulan spektrumlar ile yapılan üst yapı analizleri sonucunda elde edilmiş ve Çizelge 4'de sunulmuştur. Tank tabanı altında elde edilmiş olan kesme kuvveti ve moment değerleri tank temelinin hareket etmediği durum kabulü ile tank temel dolgusu altına da tamamen aktarılarak kayma ve taşıma gücü kontrolleri yapılmıştır. Çalışma kapsamında tank yapısı taşıma gücü analizleri tank temeli dolgusu altında (geogritle güçlendirilmiş kum-çakıl kontrollü dolgusu altında), yatayda kayma kontrolleri ise hem tank temeli (tabanı) seviyesinde hem de tank temeli dolgusu altında gerçekleştirilmiştir.

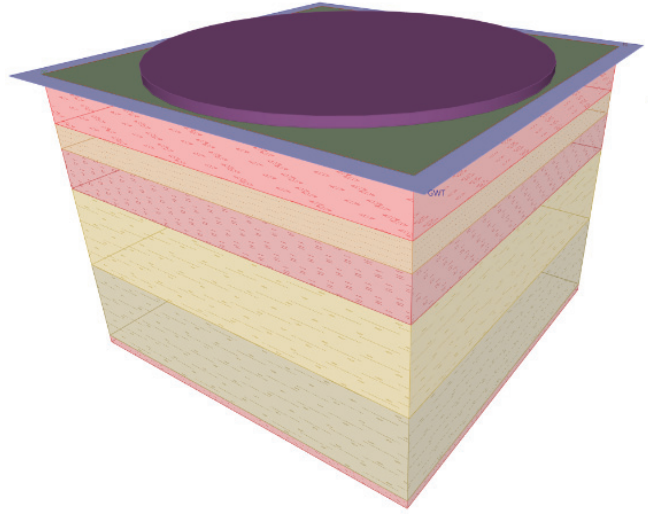

a)

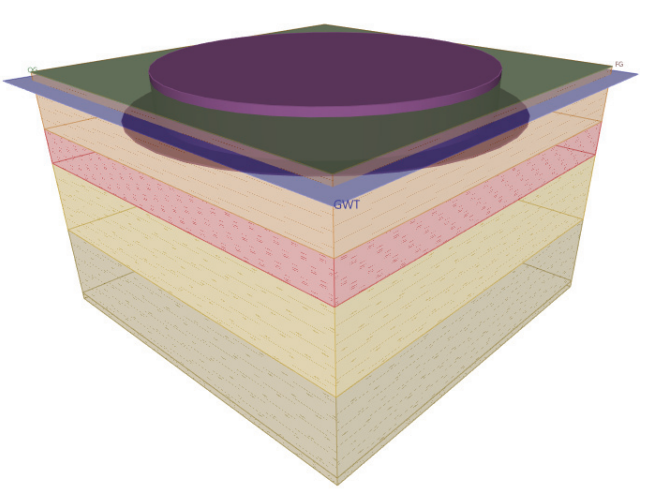

b)

Şekil 11 - a) Tank temeli altında, b) tank temel dolgusu altında yapılacak Geo5 analiz modelleri

Deprem yükleri etkisi altında tank çevresinde bulunan tank çevre duvarının stabilite analizleri TBDY 2018 esas alınarak incelenmiştir. Bu kapsamda çevre duvarının dönmeye karşı güvenliği, kaymaya karşı güvenliği ve taşıma gücü güvenliği kontrol edilmiştir. 
Çizelge 4 - Tank temeli stabilite analizlerinde kullanılan yük değerleri

\begin{tabular}{lcc}
\hline \hline & Tank Tabanı Altında & Tank Temel Dolgusu Altında \\
\hline $\begin{array}{l}\text { Depremli durumda düşey } \\
\text { yük Q (kN) }\end{array}$ & 101919 & 282220 \\
\hline $\begin{array}{l}\text { Deprem kaynaklı taban } \\
\text { kesme kuvveti } V_{\text {th }}(\mathbf{k N})\end{array}$ & 36963 & 36963 \\
\hline $\begin{array}{l}\text { Depremli durumda } \\
\text { moment M (kN.m) }\end{array}$ & 173915 & 173915 \\
\hline \hline
\end{tabular}

\subsection{Deprem Yükleri Altında Tank Temel Yapısının Taşıma Gücü ve Yatayda Kayma Kontrolleri}

Tank yapıları genel itibariyle lojistik açıdan daha uygun olması sebebiyle nehir ve deniz kıyılarındaki sahalarda inşa edilmektedir. Nehir ve deniz kenarlarındaki zemin profillerinde ise yumuşak ve/veya gevşek zemin birimleri hakimdir. İnceleme tankı Marmara denizine yaklaşık 300 metre uzaklıkta bulunmaktadır ve yer altı su seviyesi yüzeye yakın konumdadır. Ayrıca Bölüm 3'de verilen idealize zemin kesiti incelendiğinde yapı temelinin kontrollü dolgu altında genel profil itibariyle sıkışabilirliği yüksek yumuşak kile oturduğu görülmektedir (Şekil 3). Bu tür zeminler hem taşıma kapasitesi hem de oturma problemi açısından kritik durumdadırlar.

Tank temelinin deprem yükleri altında taşıma gücü analizleri TBDY 2018 esas alınarak gerçekleştirilmiştir. Buna göre yüzeysel temellerin taşıma gücü kontrolünde deprem etkilerini de içeren temel taban basıncı $\left(\mathrm{q}_{\mathrm{o}}\right)$ tasarım dayanımından $\left(\mathrm{q}_{\mathrm{t}}\right)$ küçük olmalıdır. Tasarım dayanımı ise, karakteristik dayanımın $\left(\mathrm{q}_{\mathrm{k}}\right)$, dayanım katsayısına $\left(\gamma_{R v}=1.4\right)$ 'e bölünmesiyle elde edilmektedir. Karakteristik dayanım bağıntısı Denklem 11 'de verilmiştir.

$q_{k}=c N_{c} s_{c} d_{c} i_{c} g_{c} b_{c}+q N_{q} s_{q} d_{q} i_{q} g_{q} b_{q}+0.5 \gamma B^{\prime} N_{\gamma} s_{\gamma} d_{\gamma} i_{\gamma} g_{\gamma} b_{\gamma}$

İncelemesi yapılan tank temeli altında geogritle güçlendirilmiş kum-çakıl kontrollü dolgusu yer almaktadır. Bu tarz dolgu tabakalarının etkisi yapı tabanına gelen gerilmeleri daha geniş alanlara yayarak azaltmaktır. Çalışma kapsamında tank dolu iken üst yapıdan gelecek yükler ve kontrollü kum-çakıl dolgu ağırlığı hesaplanarak kum-çakıl dolgusu tabanında (yumuşak kil tabakası üzerinde) temel taban basınc1 $\mathrm{q}_{\mathrm{o}}=171 \mathrm{kPa}$ olarak belirlenmiştir. Kil zemin üzerine taşınan tank temeli yapısının taşıma gücü analizinde depremli durumda ani yükleme durumu göz önünde bulundurularak drenajsız yükleme koşulları altında analizler gerçekleştirilmiştir. Kum tabakalarının sıvılaşma ve aşırı boşluk suyu basıncı oluşumu göz önünde bulundurularak tasarım dayanımı hesabına katılmamıştır (Day [45]). Denklem 11 kullanılarak deprem yükleri altında tasarım dayanımı temel dolgusu altında $\mathrm{q}_{\mathrm{t}}=191 \mathrm{kPa}$ olarak hesaplanmıştır ve deprem yüklemesi sonucunda temel tabanında oluşacak gerilme (temel taban basınc1), $\mathrm{q}_{\mathrm{o}}=171 \mathrm{kPa}$ dan büyük bulunmuştur.

Duncan ve D'Orazio [5] tank yapılarında taşıma gücü açısından 2 yenilme durumunun kritik olduğunu belirtmişlerdir (Şekil 12). Bunlardan ilki yönetmelik kapsamında incelemiş 
olduğumuz tank tabanı altında genel taşıma gücü yenilmesi durumudur. İkincisi ise tank çeperi altında lokal olarak göçmenin gerçekleşebileceği kenar taşıma gücü yenilmesi durumudur. Duncan ve D'Orazio [5] iki durumun da incelenmesi gerektiğini belirtmişlerdir. Yapılan kenar taşıma kapasitesi hesabı sonucunda tasarım dayanımı temel altında $\mathrm{q}_{\mathrm{t}}=172$ $\mathrm{kPa}$ olarak hesaplanmıştır ve deprem yüklemesi sonucunda temel tabanında oluşacak gerilme (temel taban basıncı), $\mathrm{q}_{\mathrm{o}}=117 \mathrm{kPa}$ dan büyük bulunmuştur. Ayrıca Bölüm 3'de bahsedildiği üzere, tank tabanında merkeze doğru uygulanan \%5 eğimin, kenar çeperinde olası bir lokal göçme potansiyelinin azaltılması için tasarlandığı düşünülmektedir. Taşıma kapasitesi açısından tankın hem taban hem de kenarda güvenli olduğu görülmüştür.

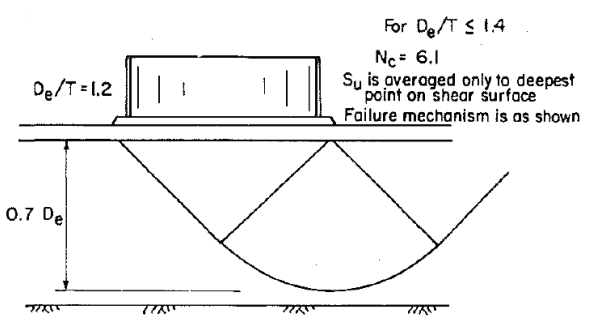

a)

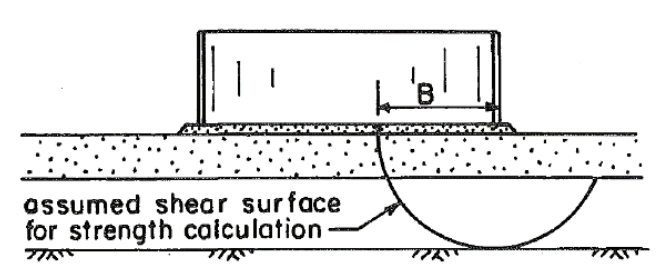

b)

Şekil 12 - a) Genel taşıma gücü mekanizması, b) Kenar taşıma gücü mekanizması

Mevcut tank temelinin deprem yükleri etkisi altında oturma miktarları konsolidasyon oturması olarak ödometrik modül kullanılarak elde edilmiştir. Yapılan analizler sonucunda tank tabanı ortasında gerçekleşecek oturma miktarı $30.4 \mathrm{~cm}$ ve tank kenarında gerçekleşecek maksimum oturma miktarı $15.5 \mathrm{~cm}$ olarak elde edilmiştir (Çizelge 6).

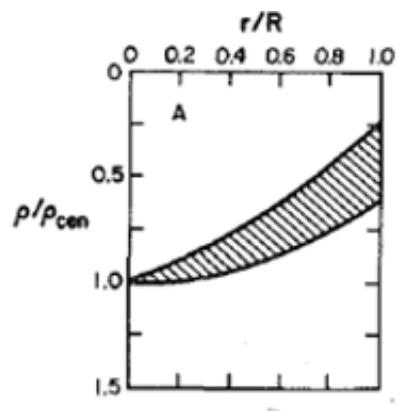

(a)

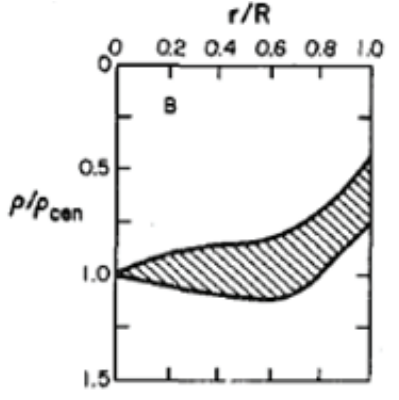

(b)

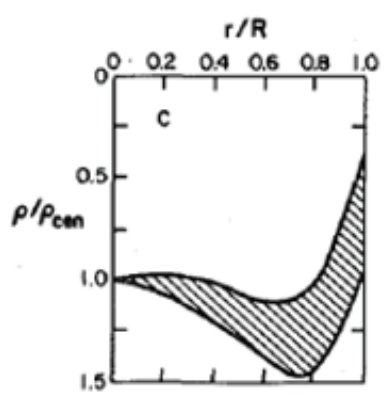

(c)

$$
\begin{aligned}
& \mathrm{p}=\text { Oturma miktarı } \\
& \mathrm{p}_{\mathrm{c}}=\text { Tank merkezindeki oturma miktarı } \\
& \mathrm{r}=\text { Tank merkezinden uzaklık } \\
& \mathrm{R}=\text { Tank yarıçapı }
\end{aligned}
$$

Şekil 13 - a) A tipi oturma profili b) B tipi oturma profili c) C tipi oturma profili 
Tank yapısı altında oluşacak farklı oturma güvenliğinin kontrolü için D'Orazio ve Duncan'ın [6] yaptığı çalışma incelenmiştir. D'Orazio ve Duncan [6] tank tabanlarında farklı oturma olması durumunda tank tabanı merkezinden kenarına doğru değişecek şekilde 3 tip (A, B, C) oturma profili şekli oluşabileceğini belirtmişlerdir. A tipi oturmada en fazla oturma merkezde olup kenarlara doğru azalmaktadır. B tipi oturma profilinde merkezden kenara doğru belli bir mesafeye kadar oturmalar aynı miktarda devam etmekte ve bir noktadan sonra azalmaya başlamaktadır. C tipi oturma profilinde ise maksimum oturma merkezden kenara olan uzaklığın 2/3'ünde gerçekleşmektedir (Şekil 13).

Tank yapısı altında gerçekleşecek oturma profili şekli yapıda meydana gelecek hasarın miktarını etkilemektedir. D'Orazio ve Duncan [6] yaptıkları çalışmalar sonucu oturma profilinin şeklini efektif tank çapı $\left(\mathrm{D}_{\mathrm{e}}\right)$ /sıkışabilir tabaka kalınlığı $(\mathrm{T})$ oranına ve minimum taşıma kapasitesine (genel taşıma kapasitesi güvenlik sayısı ve kenar taşıma kapasitesi güvenlik sayısından küçük olanı) bağlı olarak vermişlerdir (Çizelge 5).

Çizelge 5 - Oturma profili tipi belirlenmesi ve izin verilebilir farklı oturma sınırları

\begin{tabular}{lccc}
\hline \hline & A tipi & B tipi & C tipi \\
\hline $\mathbf{D}_{\mathbf{e}} / \mathbf{T}$ & $<4$ & $>4$ & \\
\hline $\mathbf{F}_{\text {min }}$ & $>1.1$ & $>1.1$ & $<1.1$ \\
\hline \hline $\begin{array}{l}\text { İzin verilebilir farklı } \\
\text { oturma sınırı }\end{array}$ & $\frac{\Delta p}{D} \leq 0.025$ & $\frac{\Delta p}{D} \leq 0.015$ & $\frac{\Delta p}{D} \leq 0.005$ \\
\hline \hline
\end{tabular}

Yaptıkları ampirik çalışma ile D'Orazio ve Duncan [6] oturma profili tiplerine bağlı olarak izin verilebilir farklı oturma limitlerini belirlemişlerdir (Çizelge 5). İnceleme tankı için efektif tank çapı $\mathrm{D}_{\mathrm{e}}=46.2 \mathrm{~m}$ ve sıkışabilir tabaka kalınlığı $\mathrm{T}>25 \mathrm{~m}$ (yapılan sondajlar sonucunda tank temeli altından 30 metreye kadar kil tabakası olduğu belirlenmiştir) için $\mathrm{De} / \mathrm{T}=1.8<4$ ve minimum taşıma kapasitesi güvenlik sayıs $\mathrm{F}_{\min }>1.1$ olarak belirlenmiştir. Çizelge 5Çizelge 5'te verilen limitlere göre inceleme tankı altında A tipi tank oturma profili oluşabileceği tahmin edilmiş ve farklı oturma miktarı $\Delta p / D=(30.4$ 15.5) $/ 4120=0.004<0.025 \quad$ olarak belirlenmiştir $(\Delta p=$ tank merkezi ve kenarı arasındaki oturma farkı, $\mathrm{D}=$ tank çapı) . Deprem yükleri etkisi altında farklı oturma açısından tankın güvenli olduğu görülmüştür.

Statik ve deprem yükleri etkisi altında oluşacak oturma miktarı, statik durumda oluşan oturma miktarından pek farklılık göstermemiştir. Tank yapısının statik oturmasını tamamladığı ve günümüze kadar güvenli bir şekilde temel zeminin stabilize olduğu düşünülmektedir. Sonuç olarak üst yapıdan deprem kaynaklı gelecek olan ilave yükler açısından kritik bir oturma olmayacağı anlaşılmaktadır. Ancak, Bölüm 6'da bahsedilen deprem dalgaları altında temel zeminin sıvılaşması veya yumuşaması sonucu oluşan oturmaların yüksek olduğu ve ortalama $50-55 \mathrm{~cm}$ mertebelerine gelebileceği görülmüştür. Literatürde tank tabanı ve tank duvarı arasında $60 \mathrm{~cm}$ 'ye ulaşan farklı oturmaya sahip hasarsız çalışmaya devam eden vakalar bulunmaktadır. Düzceer [8] beş adet yüzer tavanlı çelik akaryakıt depolama tankında yaptığı incelemeler sonucunda geniş çapa sahip tank 
temellerinde oluşmuş $40.8 \mathrm{~cm}$ 'lik oturmanın üst yapıda herhangi bir fonksiyon kaybına sebep olmadığını belirtmiştir. Tank yapılarında oluşacak oturma miktarları konusunda genel kabul görmüş limitler bulunmamaktadır. Ancak boru bağlantılarının bu yer değiştirmelerin oluşma ihtimali göz önünde bulundurularak revize edilmesi önerilir.

Çizelge 6 - Tank yapısı temelinin deprem yüklemesi altında taşıma gücü ve oturma miktarı kontrolü

\begin{tabular}{lc}
\hline \hline & $\begin{array}{c}\text { Tank Temel Dolgusu } \\
\text { Altında }\end{array}$ \\
\hline Tasarım dayanımı, qt (kPa) & 191 \\
\hline Temel taban basıncı, qo (kPa) & 171 \\
\hline Toplam maksimum eksantrisite, $\mathbf{e}_{\mathbf{t}}$ & $0.011<0.333$ \\
\hline $\begin{array}{l}\text { Merkezde Oturma (cm) - Statik Yükleme /Deprem Yüklemesi } \\
\text { Durumu }\end{array}$ & $30.4 / 30.4$ \\
\hline $\begin{array}{l}\text { Kenarda Max. Oturma (cm) - Statik Yükleme /Deprem } \\
\text { Yüklemesi Durumu }\end{array}$ & $14.1 / 15.5$ \\
\hline Farklı Oturma & $0.004<0.025$ \\
\hline \hline
\end{tabular}

Çizelge 7. Tank yapısı temellerinin deprem yüklemesi altında yatayda kayma kontrolü

\begin{tabular}{lcc}
\hline \hline & Tank Tabanı Altında & $\begin{array}{c}\text { Tank Temel Dolgusu } \\
\text { Altında }\end{array}$ \\
\hline Tasarım sürtünme direnci, $\mathbf{R}_{\text {th }}(\mathbf{k N})$ & 60818 & 43786 \\
\hline Tasarım pasif direnci, $\mathbf{R}_{\mathbf{p t}}(\mathbf{k N})$ & 0 & 255 \\
\hline $\mathbf{R}=\mathbf{R}_{\text {th }}+\mathbf{+} \mathbf{0 . 3} \mathbf{R}_{\mathbf{p t}}(\mathbf{k N})$ & 60818 & 43863 \\
\hline Tasarım yatay kuvveti, $\mathbf{V}_{\text {th }}(\mathbf{k N})$ & 36963 & 36963 \\
\hline \hline
\end{tabular}

Tank yapısının yatayda kayma kontrolü hem tank tabanı altında hem de kontrollü kumçakıl dolgusu altında TBDY 2018'e uygun olarak incelenmiştir. Yönetmeliğe göre yüzeysel temellerin yatayda kayması kontrolünde temel tabanında etkiyen tasarım yatay kuvveti $\left(\mathrm{V}_{\mathrm{th}}\right)$, tasarım sürtünme direnci $\left(\mathrm{R}_{\mathrm{th}}\right)$ ile tasarım pasif direncinin $\left(\mathrm{R}_{\mathrm{pt}}\right)$ \%30'unun toplamından küçük olmalıdır. İncelenen tank yapısında, tank tabanı altında yatayda kayma kontrolü hesaplarında yatayda kayma direnci (sürtünme direnci ve pasif direncin 30\%'unun toplamı) 60818 kN (R) olarak hesaplanmış olup deprem yükleri altındaki yatayda tasarım kuvvetinden $\mathrm{V}_{\mathrm{th}}=36963 \mathrm{kN}$ 'dan büyük bulunmuştur. İncelenen tank yapısında, kontrollü kum-çakıl temel dolgusu altında yatayda kayma kontrolü hesaplarında yatayda kayma direnci $45006 \mathrm{kN}$ (R) olarak hesaplanmış olup deprem yükleri altındaki yatayda tasarım kuvvetinden $\mathrm{V}_{\mathrm{th}}=36963 \mathrm{kN}$ 'dan büyük bulunmuştur. İncelenen tank yapısı için yatayda tasarım dayanımı hem temel dolgusu altında hem de asfalt tabaka ile dolgu arasında yatay deprem yüklerinin üzerinde bulunmuş olup kaymaya karşı tank tabanının güvenli olduğu tespit edilmiştir (Çizelge 7). 


\subsection{Tank Temeli Çevre Duvarının Stabilite Kontrolleri}

Çevre duvarının deprem yükleri altında zemin taşıma gücü analizi, devrilmeye ve yatayda kaymaya karşı kontrol analizleri TBDY 2018 esas alınarak gerçekleştirilmiştir. Dayanma yapısının temelinde taşıma gücü kontrolünde deprem etkilerini de içeren temel taban basıncı $\left(\mathrm{q}_{\mathrm{o}}\right)$ tasarım dayanımından $\left(\mathrm{q}_{\mathrm{t}}\right)$ küçük olmalıdır. Devrilme ve yatayda kayma tahkikinde dayanma yapısının devrilmeye ve yatayda kaymaya zorlayan etkiler (momentler/kuvvetler) ile bunlara karşı koyan etkilerin ve dirençlerin dengesi karşılaştırılmaktadır. Dayanma yapısının devrilmeye karşı güvenli olması için Denklem 12 koşulu sağlanmalıdır.

$E_{\text {dev }} \leq \frac{R_{\text {dev }}}{\gamma_{\text {Rdev }}}$

Burada, $\mathrm{E}_{\mathrm{dev}}$ devrilmeye zorlayan etkiler toplamı, $\mathrm{R}_{\mathrm{dev}}$ devrilmeye karşı koyan etkiler ve dirençler toplamı, $\gamma_{\text {Rdev }}$ ise devrilmeye karşı tasarım güvenlik katsayısıdır. Bu katsayı $\gamma_{\text {Rdev }}$ $\geq 1.3$ olarak göz önüne alınacaktır. Dayanma yapılarının yatayda kayması kontrolünde temel tabanında etkiyen tasarım yatay kuvveti $\left(\mathrm{V}_{\text {th }}\right)$, tasarım sürtünme direnci $\left(\mathrm{R}_{\text {th }}\right)$ ile tasarım pasif direncinin $\left(\mathrm{R}_{\mathrm{pt}}\right) \% 30$ 'unun toplamından küçük olmalıdır.

Çalışma kapsamında çevre duvarı analizlerinde çevre duvarının arkasında bulunan tank yapısının oluşturacağı taban basıncı çevre duvarı arkasında sürşarj yükü olarak etkitilmiştir. Çevre duvarının deprem yükleri altında düşey tasarım dayanımı $\mathrm{q}_{\mathrm{t}}=31.5 \mathrm{kPa}$ olarak hesaplanmış olup deprem yüklemesi sonucunda temel tabanında oluşan gerilme (temel taban basınc1), $\mathrm{q}_{\mathrm{o}}=28.9 \mathrm{kPa}$ dan büyük bulunmuştur. Çevre duvarı yapısında, devrilmeye karşı kontrol hesabında devrilmeye zorlayan etkiler toplamı $E_{\mathrm{dev}}=72 \mathrm{kNm} / \mathrm{m}$ olarak hesaplanmış olup deprem yükleri altında devrilmeye karşı koyan etkiler toplamı $R_{\text {dev }}=122$ $\mathrm{kNm} / \mathrm{m}$ 'den küçük bulunmuştur. Çevre duvarı yapısında, yatayda kayma kontrolü hesaplarında yatayda kayma direnci (sürtünme direnci ve pasif direncin 30\%'unun toplamı) $78 \mathrm{kN}(\mathrm{R})$ olarak hesaplanmış olup deprem yükleri altındaki yatayda tasarım kuvvetinden $\mathrm{V}_{\mathrm{th}}=29 \mathrm{kN}$ 'dan büyük bulunmuştur. Sonuçlar Çizelge 8'de sunulmuştur.

\section{Çizelge 8 - Tank çevre duvarının stabilite kontrolleri}

\begin{tabular}{|c|c|c|}
\hline \multirow{2}{*}{$\begin{array}{l}\text { Taşıma Gücü } \\
\text { Analizi }\end{array}$} & Tasarım dayanımı, $\mathrm{q}_{\mathrm{t}}(\mathrm{kPa})$ & 31.5 \\
\hline & Temel taban basincı, qo $(\mathrm{kPa})$ & 28.9 \\
\hline \multirow{2}{*}{$\begin{array}{c}\text { Devrilmeye } \\
\text { Karş1 Kontrol } \\
\text { Analizi }\end{array}$} & Devrilmeye zorlayan etkiler toplamı, $\mathrm{E}_{\operatorname{dev}}(\mathrm{kN} . \mathrm{m} / \mathrm{m})$ & 72 \\
\hline & Devrilmeye karşı koyan etkiler toplamı, $\mathrm{R}_{\text {dev }}(\mathrm{kN} . \mathrm{m} / \mathrm{m})$ & 122 \\
\hline \multirow{4}{*}{$\begin{array}{c}\text { Yatayda } \\
\text { Kaymaya Karş1 } \\
\text { Kontrol Analizi }\end{array}$} & Tasarım sürtünme direnci, $\mathrm{R}_{\text {th }}(\mathrm{kN})$ & 54 \\
\hline & Tasarım pasif direnci, $\mathrm{R}_{\mathrm{pt}}(\mathrm{kN})$ & 79 \\
\hline & $\mathrm{R}=\mathrm{R}_{\mathrm{th}}+0.3 \mathrm{R}_{\mathrm{pt}}(\mathrm{kN})$ & 78 \\
\hline & Tasarım yatay kuvveti, $\mathrm{V}_{\text {th }}(\mathrm{kN})$ & 29 \\
\hline
\end{tabular}




\section{SONUÇLAR}

$\mathrm{Bu}$ yayın deprem bölgesinde bulunan mevcut bir endüstriyel tank yapısının Uluslararası Standartlara, TBDY 2018 'e ve literatürde tank yapıları için önerilen kriterler esas alınarak, deprem kayıtlarının belirlenmesi ve ölçeklendirmesi, temel zemininde yumuşama ve sıvılaşma davranışlarının irdelenmesi, temel zemini mukavemeti, stabilite ve oturma analizlerinin değerlendirmesi üzerine bir örnek çalışma sunmaktadır. Tank yapılarının içinde bulundukları kimyasal sıvıların yanıcı etkileri olması sebebiyle statik olarak güvenli olsa da deprem yükleri altında riskli durumlar ortaya çıkabilmektedir. Bu çalışmada bu riskler geoteknik açıdan irdelenmiş, stabilite kontrolleri ve oturma analizleri gerçekleştirilerek alınması gereken önlemlerden bahsedilmiştir. Endüstriyel tank yapıları için henüz ülkemizde bir yönetmelik bulunmaması sebebiyle bu çalışmanın gelecekte yönetmelik çalışmalarına da bir ışık tutacağı umut edilmektedir.

Yüzer çatı tipine sahip inceleme tank1 41.7 m çapında ve 12 m yüksekliğinde, 16000 m3'lük iç hacime sahip olup yüzeyden $4 \mathrm{~m}$ derinlikten itibaren kum-çakıl dolgu malzemesi ile 50 cm'lik tabakalar halinde doldurulmuş ve sıkıştırılmış ve 7 seviye geogrit malzeme serilerek güçlendirme gerçekleştirilmiş bir dolgu temel üzerine oturtulmuştur. Tank tabanı $10 \mathrm{~cm}$ kalınlığında tankın ortasına doğru \%5 eğimli mastik asfalt ile kaplanmıştır. 7. geogrit tabakasının üzerine tekrar kum-çakıl dolgusu yapılarak tankın tabanı bu tabaka üzerine oturtulmuştur. Kum-çakıl dolgu malzemesi ve 7 tabaka geogritle güçlendirilmiş zemin üzerine tank taban dolgusunu çevreleyen betonarme temel çevre duvarı inşa edilmiştir. Deprem yükleri altında içerisinde yanıcı kimyasal bulunduran tanklarda çalkalanma etkisi kritik durum arz etmektedir. Fakat inceleme tankı yüzer çatı tipine sahip olmasından dolayı bu çalkalanma etkisi sınırlandırılmıştır.

Marmara bölgesinde diri fay hatlarına yakın mesafede (10-50 km arasi) bulunmakta olan tank yapısının bulunduğu sahada yoğunlukla deniz alüvyonu zemini bulunmakta ve zemin profili 0.0-3.5 m arasında dolgu tabakası, 3.5-7.0 m arasında silt içerikli düşük plastisiteli çok yumuşak kil tabakası, 7.0-11.5 m arasında çakıl içerikli killi orta sıkı kum tabakası, 11.5-20.0 m arasında silt içerikli kum arabantlı yumuşak kil tabakası ve 20.0-30.0 m arasında silt içerikli kum ara bantlı orta katı-katı kil tabakası olarak tahmin edilmiştir. Sahada yapılan jeofizik deneylere göre ilk $30 \mathrm{~m}$ kayma dalgası hızı $\left(\mathrm{V}_{\mathrm{s}}\right)_{30}=109 \mathrm{~m} / \mathrm{s}$ olarak hesaplanmıştır. Yerel zemin sınıfı ZE olarak belirlenmekle beraber sahada bulunan kumlu birimlerde sıvılaşma potansiyeli ZE sınıfı tasarım spektrumu esas alınarak incelenmiştir Sahada yapılan 3 sondajın verileri ile gerçekleştirilen sıvılaşma analizlerine göre yüzeyden 4 m-10 m derinlikleri arasında değişkenlik gösteren orta sıkı kum tabakalarında sıvılaşmaya karşı güvenlik sayıları 1.10'un altında elde edilmiştir. Sıvılaşma potansiyeli bulunması ve sahada kayma mukavemeti düşük 35 m'den kalın kil tabakalarının mevcut olması sebebiyle zemin sınıfının ZF olarak ele alınıp zaman tanım alanında doğrusal olmayan sahaya özel zemin davranış analizleri gerçekleştirilmiştir. Doğrusal olmayan analizler, sahada $150 \mathrm{~m}$ derinliğe kadar yapılan 2B MASW arazi deneyi sonucunda anakaya derinliğine $150 \mathrm{~m}$ 'de ulaşılamamış olması ve anakayanın $300 \mathrm{~m}$ kadar derinde olduğu tahmin edilmesi sebebiyle ZD hedef spektrumuna göre ölçeklendirilmiş 11 adet yer hareketi ivme-zaman mostra kaydı kullanılarak gerçekleştirilmiştir. Sahaya özel zemin davranış analizleri doğrusal olmayan GQ/H modeli ile boşluk suyu basıncı modelleri kullanılmadan ve doğrusal olmayan MKZ modeli ile hem kum hem de kil zeminlerde boşluk suyu basıncı modelleri kullanılarak ayrı ayrı gerçekleştirilmiştir. Serbest saha analiz sonuçlarına göre ve literatürdeki olasılıksal 
modeller kullanılarak serbest sahada yatay yer değiştirmeler tahmin edilmiştir. MKZ modeli ile yapılan analiz sonuçlarında her tabakada oluşan boşluk suyu basıncını konsolidasyon oturmasına dönüştürerek ve yine literatürdeki modeller kullanılarak serbest sahada düşey deformasyonlar tahmin edilmiş ve karşılaştırılmıştır. Ayrıca tank yapısı altında düşey yer değiştirmeler tahmin edilmiştir. Tank yapısı tabanında, güçlendirilmiş geogritli dolgu altında ve temel çevre duvarı için deprem yükleri altında taşıma gücü ve yatayda kayma kontrolleri ve çevre duvarı için devrilme kontrolleri yapılmıştır.

Sahaya özel zemin davranış analiz sonuçlarına göre boşluk suyu basıncı modelleriyle yüzeyde elde edilen ivme tepki spektrumlarının boşluk suyu basıncı modeli kullanılmadan elde edilen yüzey spektrumlarının çok altında değerler verdiği ve zemin yumuşaması ve sıvılaşmasının doğal bir izolatör gibi davranarak yüzey ivmelerini ciddi oranda sönümlediği gözlemlenmiştir. Ancak deprem yükleri altında zemin sıvılaşması ve yumuşaması serbest sahada yüksek mertebelerde yanal yer değiştirmelere (2.0-2.3 m) ve düşey oturmalara (58$128 \mathrm{~cm}$ ) sebebiyet vermiştir. Tank yapısı altında deprem yükleri kaynaklı zemin sıvılaşması ve yumuşaması sonucu oluşan düşey oturmaların tahmini için, birçok parametrenin etkisindeki belirsizlikler sebebiyle halen literatürde kısıtlı sayıda olasılıksal model bulunmaktadır. $\mathrm{Bu}$ çalışmada kullanılan modelle yapılan hesaplamalar sonucunda tank yapısı altında $50-55 \mathrm{~cm}$ oturma tahmin edilmiş olup, serbest saha tahminlerinden daha düşüktür. Tank yapısı altında $4.5 \mathrm{~m}$ derinliğe kadar sıkıştırtılmış geogritli dolgunun bulunması sebebiyle serbest sahadan daha az oturma bekleneceği tahmin edilebilir. Bu oturma değerlerinin tank yapılarının sağlıklı bir şekilde çalışması için limit sınırlar içerisinde kaldığı literatürde bahsedilmiş olup tank yapısı altında bir iyileştirme önerilmemiştir. Tank yapısı altındaki ince asfalt temel yapısının merkeze doğru 5\% eğimli olması ve 4.0-4.5 m temel dolgusu bulunması sebebiyle tank temelinde dönme olasılığının düşük olduğu tahmin edilmiştir. Ancak bu tür tank yapılarının sıvılaşma ve yumuşama potansiyeli olan zeminlerin üzerinde dolgu temel ile tasarımlarının incelenmesi ve araştırılması önem arz etmektedir.

$\mathrm{Bu}$ tür geniş bir sahada zemin iyileştirmesi yapılması ve her tank yapısının temel altı zeminin iyileştirilmesi bir çözüm olarak önerilebilir. Ancak tank yapılarının tolere edebileceği oturmaların söz konusu olması sebebiyle böyle bir iyileştirmenin tüm sahada uygulanması pek pratik görülmemektedir. Sadece tank yapısı altında yapılacak olan iyileştirme ise boru bağlantılarındaki farklı deformasyonları daha da arttıracaktır. Bu sebeple burada kritik olan serbest saha ve tank yapısı arasındaki farklı oturmaların boru bağlantıları tarafından karşılanabilecek düzeyde bağlantıların esnek tasarlanması veya revize edilmesi önem arz etmektedir. Serbest saha ile tank yapısı arasındaki farklı oturmanın yaklaşık en fazla 70-80 cm, en düşük ise 5-10 cm mertebelerinde olduğu tahmin edilmektedir. Tank yapısı ile serbest saha arasındaki boru bağlantılarında bu yer değiştirme farkının göz önünde bulundurulması önerilir. Üst yapıdan gelecek olan ilave deprem yükleri altında tank yapısı tabanında ve geogritli dolgu altında taşıma gücü ve tabanda kayma kontrolleri yapılmış ve güvenli bulunmuştur. Tank temeli çevre duvarı taşıma gücü, yatayda kayma ve devrilmeye karşı güvenli bulunmuştur.

Endüstriyel tank yapılarının deprem bölgelerinde tasarımında ve mevcut yapıların sismik stabilite analizleri ile ilgili literatürde kısıtlı sayıda çalışma bulunması sebebiyle mevcut bir tank yapısının geoteknik açıdan değerlendirmesi bu çalışmada sunulmuş olup, bu tür yapılar için yönetmelik çalışmalarının gerekliliğine dikkat çekilmiştir. 


\section{Semboller}
A
Model parametresi
B
Temel genişliği
$\mathrm{b}_{\mathrm{c}}, \mathrm{b}_{\mathrm{q}}, \mathrm{b}_{\gamma}$
Temel taban eğimi düzeltme katsayıları
BSB
Boşluk suyu basıncı
c
Zeminin kohezyon dayanımı
$\mathrm{CH}$
Kroshol deneyi (crosshole)
$\mathrm{C}_{\mathrm{M}}$
Deprem büyüklüğü düzeltme katsayısı
$\mathrm{CRR}_{\mathrm{M} 7.5}$
Çevrimsel dayanım oranı
$\mathrm{CSR}_{\mathrm{SS}, 20,1-\mathrm{D}, 1 \mathrm{~atm}}$
1 boyutlu basit kesme deneylerinde 20 . çevrimde $100 \mathrm{kPa}$ düşey gerilme altında çevrimsel gerilme direnci oranını

\section{CSR $_{\text {SSEI }}$}
Yapı-zemin etkileşimini dikkate alan sismik kayma gerilme oranı
$\mathrm{c}_{\mathrm{u}}$
Drenajsız kayma dayanımı
$\left(\mathrm{c}_{\mathrm{u}}\right)_{30}$
Temel tabanından itibaren 30 metre derinliğe kadarki ortalama drenajsız kayma dayanımı
$\mathrm{D}$
Sönüm oranı, Tank çapı
DD
Deprem düzeyi
$\mathrm{D}_{\mathrm{e}}$
Efektif tank çapı
$\mathrm{d}_{\mathrm{c}}, \mathrm{d}_{\mathrm{q}}, \mathrm{d}_{\gamma}$
Temel derinliği düzeltme katsayıları
$\mathrm{DPI}_{\mathrm{dev}}$
Deviatorik Yerdeğiştirme potansiyeli indeksi (Deviatoric Displacement Potential Index)
$\mathrm{DPI}_{\mathrm{vol}}$
Hacimsel Yerdeğiştirme potansiyeli indeksi (Volumetric Displacement Potential Index)
DTS Deprem tasarım sinıfi
$\mathrm{E}$
Deformasyon modülü
$\mathrm{E}_{\mathrm{dev}}$
Dayanma yapısını devrilmeye zorlayan etkiler toplamı
$\mathrm{E}_{\text {oed }}$
Hacimsel sıkışma modülü
FC
İnce dane oranı
$F_{\min }$
Minimum taşıma kapasitesi güvenlik sayısı
$\mathrm{f}_{\text {maks }}$
Maksimum frekans
Fs
Kısa periyot bölgesi için yerel zemin etki katsayısı
$\mathrm{F}_{1}$
1.0 saniye periyot için yerel zemin etki katsayısı
G
Kayma modülü
$\mathrm{g}_{\mathrm{c}}, \mathrm{g}_{\mathrm{q}}, \mathrm{g}_{\gamma}$
Zemin eğimi düzeltme katsayıları
$\mathrm{G}_{\text {maks }}$
Maksimum kayma modülü
$\mathrm{G}_{\mathrm{s}}$
Güvenlik sayısı 


\begin{tabular}{|c|c|}
\hline h & Yap1 yüksekliği \\
\hline $\mathrm{i}_{\mathrm{c}}, \mathrm{i}_{\mathrm{q}}, \mathrm{i}_{\gamma}$ & Yükleme eğikliği düzeltme katsayıları \\
\hline $\mathrm{I}_{\mathrm{P}}$ & Plastisite indisi \\
\hline $\mathrm{K}_{\mathrm{md}}$ & Çok yönlü deprem hareketi için düzeltme katsayısı \\
\hline $\mathrm{K}_{\mathrm{MW}}$ & Deprem büyüklüğü için düzeltme katsayısı \\
\hline $\mathrm{K}_{\sigma}$ & Efektif gerilme düzeltme katsayısı \\
\hline LL & Likit limit \\
\hline $\mathrm{L}_{\max }$ & En büyük yanal yerdeğiştirme \\
\hline M & Eğilme momenti \\
\hline MASW & Çok kanallı yüzey dalgası analiz yöntemi \\
\hline $\mathrm{M}_{\mathrm{w}}$ & Moment büyüklüğü \\
\hline $\mathrm{N}_{\mathrm{c}}, \mathrm{N}_{\mathrm{q}}, \mathrm{N}_{\gamma}$ & Taşıma gücü katsayıları \\
\hline $\mathrm{N}_{60}$ & Düzeltilmiş SPT değeri \\
\hline$\left(\mathrm{N}_{60}\right)_{30}$ & $\begin{array}{l}\text { Temel tabanından itibaren } 30 \text { metre derinliğe kadarki ortalama standart } \\
\text { penetrasyon darbe sayısı }\end{array}$ \\
\hline $\mathrm{N}_{1,60 \mathrm{cs}}$ & Temiz kumlar için düzeltilmiş SPT vuruş sayısı \\
\hline $\mathrm{N}_{1,60 \mathrm{f}}$ & İnce dane içeriğine göre düzeltilmiş SPT vuruş sayısı \\
\hline pga & En büyük yer ivmesi \\
\hline PI & Plastisite indisi \\
\hline$P_{1}$ ve $P_{2}$ & Model parametreleri \\
\hline $\mathrm{R}_{\mathrm{dev}}$ & $\begin{array}{l}\text { Dayanma yapısında devrilmeye karşı koyan etkiler ve dirençler } \\
\text { toplamı }\end{array}$ \\
\hline $\mathrm{R}_{\mathrm{jb}}$ & Faya olan uzaklık (Joyner-Boore mesafesi) \\
\hline$R_{\mathrm{pt}}$ & Tasarım pasif direnci \\
\hline$R_{\text {th }}$ & Tasarım sürtünme direnci \\
\hline$r_{u}$ & Boşluk suyu basıncı oranı \\
\hline Q & Deprem durumunda düşey yük \\
\hline$q_{\mathrm{k}}$ & Temel taşıma gücü karakteristik dayanımı \\
\hline$q_{\mathrm{o}}$ & $\begin{array}{l}\text { Temel seviyesinde etkiyen düşey yük, kesme ve moment etkilerinin } \\
\text { oluşturduğu temel taban basıncı }\end{array}$ \\
\hline$q_{\mathrm{t}}$ & Temel taşıma gücü tasarım dayanımı \\
\hline $\mathrm{s}$ & Model parametresi \\
\hline $\mathrm{S}$ & Sismik kırılma ölçü lokasyonu \\
\hline $\mathrm{S}_{\mathrm{c}}, \mathrm{S}_{\mathrm{q}}, \mathrm{S}_{\gamma}$ & Temel şekli düzeltme katsayıları \\
\hline $\mathrm{S}_{\mathrm{DS}}$ & Kisa periyot tasarım spektral ivme katsayısı \\
\hline $\mathrm{S}_{\mathrm{D} 1}$ & 1.0 saniye periyot için tasarım spektral ivme katsayısı \\
\hline
\end{tabular}


SK

$\mathrm{S}_{\max }$

SPT

$\mathrm{S}_{\mathrm{S}}$

$\mathrm{S}_{1}$

$\mathrm{T}$

TBDY

TDTH

UU

$\mathrm{V}_{\mathrm{s}}$

$\mathrm{V}_{\mathrm{s}, 30}$

$\mathrm{V}_{\mathrm{s}, \text { final }}$

$V_{\text {th }}$

$v^{\prime}$

$\mathrm{W}_{\mathrm{c}}$

$\beta$

$\Delta \mathrm{p}$

$\phi^{\prime}$

$\gamma_{\max }$

$\gamma_{\mathrm{n}}$

$\gamma_{\text {Rdev }}$

$\gamma_{\text {ref }}$

$\gamma_{\mathrm{RV}}$

$\rho$

$\sigma_{\mathrm{V}}^{\prime}$

$\tau$

$\tau_{\mathrm{cyc}}$

$\tau_{\max }$

$\tau_{\mathrm{R}}$

$\tau_{\mathrm{st}}$

$\theta_{1,2,3,4,5}$

Sondaj kuyusu

En büyük düşey yerdeğiştirme/oturma

Standart penetrasyon deneyi

Kisa periyot harita spektral ivme katsayıs1

1.0 saniye periyot için harita spektral ivme katsayısı

Periyot, Sıkışabilir tabaka kalınlığ

Türk bina deprem yönetmeliği

Türkiye deprem tehlike haritaları

Konsolidasyonsuz-drenajsız üç eksenli basınç deneyi

Kayma dalgası hızı

Temel tabanından itibaren 30 metre derinliğe kadarki ortalama kayma dalgası hızı

Sahaya özel analizler sonucu azalmış kayma dalgası hızı

Temel tabanında etkiyen tasarım yatay kuvveti

Poisson oran1

Su muhtevas1

Model parametresi

Tank merkezi ve kenarı arasındaki oturma miktarı farkı

Zeminin efektif kayma direnci açısı

Maksimum yatay şekil değiştirme

Doğal birim hacim ağırlık

Dayanma yapısında devrilmeye karşı tasarım güvenlik sayısı

Referans şekildeğiştirme değeri

Temel taşıma gücü dayanım katsayısı

Yoğunluk

Düşey efektif gerilme

Kayma gerilmesi

Çevrimssel kayma gerilmesi

Maksimum kayma dayanımı

Sıvılaşma direnci

Statik kayma gerilmesi

Model parametresi 


\section{Kaynaklar}

[1] API Standard 650, Welded Steel Tanks for Oil Storage, 12th Edition, American Petroleum Institute, Washington DC, USA, 2013.

[2] ASCE/SEI 7-10, Minimum design loads for buildings and other structures, Reston, VA: ASCE, 2013.

[3] EN 1991-4, Eurocode 1: Actions on structures - Part 4: Silos and tanks, European Committee for Standardization, 2006.

[4] New Zealand Society of Earthquake Engineeing (NZSEE), Seismic Design of Storage Tanks: 2009, Recommendations of a NZSEE Study Group on Seismic Design of Storage Tanks, Wellington, New Zealand, 2009.

[5] Duncan, J. M., and D'Orazio, T. B., Stability of steel oil storage tanks. Journal of Geotechnical Engineering, 110(9), 1219-1238, 1984.

[6] D'Orazio, T. B., and Duncan, J. M., Differential settlements in steel tanks. Journal of Geotechnical Engineering, 113(9), 967-983, 1987.

[7] Kumbasar V., Silindirik Tankların Temel Hesapları, 641, İTÜ Kütüphanesi, 1966.

[8] Düzceer, R., Akaryakıt tank temellerinin hesaplanan ve ölçülen oturmaları, Zemin Mekaniği ve Temel Mühendisliği 1. Özel Konulu Sempozyumu, İstanbul, Türkiye, 2007.

[9] Ramdane, B., Omar, S., and Djahid, A., Differential Settlements of Cylindrical Steel Storage Tanks: Case of the Marine Terminal of Bejaia, Seventh International Conference on Case Histories in Geotechnical Engineering, Chicago, USA, 2013.

[10] Kamyab, H., and Palmer, S. C., Displacements in oil storage tanks caused by localized differential settlement. Journal of Pressure Vessel Technology, 113, 71-80, 1991.

[11] Sento, N., Yasuda, S., Yoshida, N., and Harada, K., Case Studies for Oil Tank on Liquefiable Sandy Ground Subjected to Extremely Large Earthquakes and Countermeasure Effects by Compaction, 13th World Conference on Earthquake Engineering, Vancouver, Canada, 2004.

[12] Cubrinovski, M., Ishihara, K., and Kijima, T., Effects of Liquefaction on Seismis Response of a Storage Tank on Pile Foundations. Proceedings: Fourth International Conference on Recent Advances in Geotechnical Earthquake Engineering and Soil Dynamics and Symposium in Honor of Professor W.D. Liam Finn, Paper No 6.15, California, 2001.

[13] TBDY, Türkiye Bina Deprem Yönetmeliği, AFAD, Türkiye, 2018.

[14] Stroud, M. A., The Standard Penetration Test in Insensitive Clays and Soft Rocks. Proceedings of the European Symposium on Penetration Testing, 2(2): 367-375, Stockholm, 1974.

[15] Baguelin, F., The pressuremeter and foundation engineering. Series on Rock and Soil Mechanics, 2(4), 617, 1978. 
[16] Hatanaka, M., and Uchida, A., Emprical Correlation between Penetration Resistance and Internal Friction Angle of Sandy Soils. Soils and Foundations, Vol. 36, No.4, pp. 1-10, 1996.

[17] Kulhawy, F.H., and Mayne, P.W., Manual on Estimating Soil Properties for Foundation Design. Electric Power Research Institute, Palo Alto, California, 1990.

[18] Briaud J.L., ,The Pressuremete, A.A. Balkema, Rotterdam, Netherlands, 1992.

[19] Akkar, S., Azak Eroğlu, T., Çan, T., Çeken, U., Demircioğlu M.B., Duman, T., Ergintav, S., Kadirioğlu, F.T., Kalafat, D., Kale, Ö., Kartal R.F., Kılıç, T., Özalp, S., Şeşetyan, K., Tekin, S., Yakıt, A., Yılmaz, M.T., ve Zülfikar, Ö., Türkiye Sismik Tehlike Haritasının Güncellenmesi. AFAD, Proje No: UDAP-Ç-13-06, 2014.

[20] Youd, T. L., and Idriss, I. M., Liquefaction resistance of soils: summary report from the 1996 NCEER and 1998 NCEER/NSF workshops on evaluation of liquefaction resistance of soils. Journal of geotechnical and geoenvironmental engineering, 127(4), 297-313, 2001.

[21] Dikmen, Ü., Başokur. A.T., Akkaya, İ., ve Arısoy, M.Ö., Yüzey dalgalarının çokkanallı analiz yönteminde uygun atış mesafesinin seçimi. Hacettepe Üniversitesi Yerbilimleri Uygulama ve Araştırma Merkezi Dergisi, 31(1), 23-32, 2009.

[22] Hashash, Y.M.A., Musgrove, M.I., Harmon, J.A., Ilhan, O., Groholski, D.R., Phillips, C.A., and Park, D., DEEPSOIL 7.0, User Manual. 2017.

[23] Skempton, A. W., Discussion: Sensitivity of clays and the $\mathrm{c} / \mathrm{p}$ ratio in normally consolidated clays. Proceedings of the American Society of Civil Engineers, Separate, 478, 19-22, 1954.

[24] Darendeli, M.B., Development of a new family of normalized modulus reduction and material damping curves. Ph.D. Dissertation, The University of Texas at Austin, 2001.

[25] Pacific Earthquake Engineering Research (PEER) Center, PEER Strong Motion Database, http://peer.berkeley.edu/smcat/, 2006.

[26] SeismoMatch 2020. A computer program for spectrum matching of earthquake records, https://seismosoft.com, 2020

[27] Tokimatsu, K., and Seed, H. B., Simplified procedures of the evaluation of settlements in clean sands. Rep. No. UCB/GT-84/16, University of California, USA, 1984.

[28] Tokimatsu, K., and Seed, H. B., Evaluation of settlements in sands due to earthquake shaking. Journal of Geotechnical Engineering, 113(8), 861-878, 1987.

[29] Ishihara, K., and Yoshimine, M., Evaluation of settlements in sand deposits following liquefaction during earthquakes. Soils and foundations, 32(1), 173-188, 1992.

[30] Shamoto, Y., Zhang, J. M., and Tokimatsu, K., New charts for predicting large residual post-liquefaction ground deformation. Soil dynamics and earthquake engineering, 17(7-8), 427-438, 1998.

[31] Youd, T. L., Hansen, C. M., and Bartlett, S. F., Revised multilinear regression equations for prediction of lateral spread displacement. Journal of Geotechnical and Geoenvironmental Engineering, 128(12), 1007-1017, 2002. 
[32] Wu, J., Seed, R. B., and Pestana, J. M., Liquefaction triggering and post liquefaction deformations of Monterey 0/30 sand under unidirectional cyclic simple shear loading. Geotechnical Engineering Research Rep. No. UCB/GE-2003/01, University of California, USA, 2003.

[33] Zhang, G., Robertson, P. K., and Brachman, R. W. I., Estimating liquefaction-induced lateral displacements using the standard penetration test or cone penetration test. Journal of Geotechnical and Geoenvironmental Engineering, 130(8), 861-871, 2004.

[34] Cetin, K. O., Bilge, H. T., Wu, J., Kammerer, A. M., and Seed, R. B., Probabilistic model for the assessment of cyclically induced reconsolidation (volumetric) settlements. Journal of Geotechnical and Geoenvironmental Engineering, 135(3), 387398, 2009.

[35] Yasuhara, K., Konami, T., Hyodo, and Hirao, K., M., Earthquake-Induced Settlement in Soft Grounds, Second International Conference on Recent Advances in Geotechnical Earthquake Engineering Soil Dynamics, Missouri, 1991.

[36] Erken, A., Özay, R., Kaya, Z., ve Ülker, M.B.C, Elibol, B., Depremler Sırasında Zeminlerin Sıvılaşması ve Taşıma Gücü Kayıpları, Türkiye Mühendislik Haberleri, 431(3), 2004.

[37] Unutmaz, B., and Cetin, K. O., Post-cyclic settlement and tilting potential of mat foundations. Soil Dynamics and Earthquake Engineering, 43, 271-286, 2012.

[38] Bilge, H. T., and Cetin, K. O., Probabilistic assessment of cyclic soil straining in finegrained soils. Geotechnical Earthquake Engineering and Soil Dynamics IV, (pp. 110), 2008.

[39] Chiaradonna, A., Bilotta, E., d'Onofrio, A.,. Flora, A. and Silvestri, F., A Simplified Procedure for Evaluating Post-Seismic Settlements in Liquefiable Soils. Geotechnical Earthquake Engineering and Soil Dynamics V, Austin, Texas, 2018.

[40] Dashti, S., Bray, J.D., Pestana, J.M., Riemer, M., and Wilson, D., Mechanisms of seismically induced settlement of buildings with shallow foundations on liquefiable soil. Journal of Geotechnical and Geoenvironmental Engineering, 136(1), 151-164, 2010a.

[41] Dashti, S., Bray, J.D., Pestana, J.M., Riemer, M., and Wilson, D., Centrifuge Testing to Evaluate and Mitigate Liquefaction-Induced Building Settlement Mechanisms. Journal of Geotechnical and Geoenvironmental Engineering, 136(7), 918-929, 2010b.

[42] Lu, C.W., A Simplified Calculation Method for Liquefaction-Induced Settlement of Shallow Foundation. Journal of Earthquake Engineering, 21:8, 1385-1405, 2017.

[43] Bray, J.D., Macedo, J., 6th Ishihara lecture: Simplified procedure for estimating liquefaction-induced building settlement. Soil Dynamics and Earthquake Engineering, 102, 215-231, 2017.

[44] Fine. GEO5 2020-Spread Footing. http://www.finesoftware.eu/, Prague, Czech Rebuplic, 2020.

[45] Day, R.W., Geotechnical Earthquake Engineering Handbook: With the 2012 International Building Code. McGraw-Hill Education, 2012. 